\title{
Morpho-molecular diversity and phylogeny of Bysmatrum (Dinophyceae) from the South China Sea and France
}

\author{
Luo Zhaohe ${ }^{1}$, Lim Zhen Fei ${ }^{2}$, Mertens Kenneth ${ }^{3,{ }^{*}}$, Gurdebeke Pieter ${ }^{4}$, Bogus Kara ${ }^{5}$, \\ Carbonell-Moore Maria Consuelo ${ }^{6}$, Vrielinck Henk ${ }^{7}$, Leaw Chui Pin ${ }^{2}$, Lim Po Teen ${ }^{2}$, \\ Chomérat Nicolas ${ }^{3}$, Li Xintian ${ }^{1}$, Gu Haifeng ${ }^{1}$
}

${ }^{1}$ Third Institute of Oceanography, SOA, Xiamen 361005, China

2 Institute of Ocean and Earth Sciences, University of Malaya, 16310 Bachok, Kelantan, Malaysia

${ }^{3}$ Ifremer, LER BO, Station de Biologie Marine, Place de la Croix, BP40537, F-29185 Concarneau

CEDEX, France

${ }^{4}$ Research Unit Palaeontology, Department of Geology, Ghent University, Krijgslaan 281, S8, B-9000

Gent, Belgium

${ }^{5}$ International Ocean Discovery Program, Texas A\&M University, College Station, TX, 77845, USA

${ }^{6}$ Oregon State University, Department of Botany and Plant Pathology, College of Agricultural Sciences, 2082 Cordley Hall, Corvallis, OR 97331-2902, USA

${ }^{7}$ Department of Solid State Sciences, Ghent University, Krijgslaan 281, S1, B-9000 Gent, Belgium

* Corresponding author : Kenneth Mertens, email address : Kenneth.Mertens@ifremer.fr

\begin{abstract}
:
The dinoflagellate genus Bysmatrum encompasses five epibenthic or tide-pool species and has been characterized by separated anterior intercalary plates. In the present study, we obtained six strains of Bysmatrum from the South China Sea and French Atlantic coast by isolating single cells/cysts from plankton and sediment samples. All strains were examined with light microscopy and scanning electron microscopy. Based on morphological observations, three strains were identified as Bysmatrum subsalsum, characterized by the elongated and rectangular first and a hexagonal second anterior intercalary plate. They differ from each other in the number of sulcal lists and the configuration of the first anterior intercalary plate. One strain was identified as Bysmatrum gregarium and the other two as Bysmatrum granulosum. The cyst-theca relationship of B. subsalsum from the French Atlantic was established by incubation of the cyst, and the geochemical composition of the cyst wall was measured through micro-Fourier transform infrared spectroscopy. Bysmatrum subsalsum from Malaysia shows a bright red stigma in the sulcal area under light microscopy, which was confirmed with transmission electron microscopy: it was identified as a type B eyespot. Small subunit ribosomal DNA (SSU rDNA), partial large subunit ribosomal DNA (LSU rDNA) and internal transcribed spacer (ITS) sequences were obtained from all six strains. The maximum likelihood and Bayesian inference analysis based on concatenated SSU, ITS and LSU sequences revealed that Bysmatrum is monophyletic and nested within Peridiniales. Our strains of B. subsalsum form a new ribotype in the molecular phylogeny (designated as ribotype B). The genetic distance based on ITS sequences among Bysmatrum species ranged from 0.34 to 0.47 and those genetic distances at the intraspecific level of $B$. subsalsum could
\end{abstract}


reach 0.41 , supporting the possibility of hidden crypticity within B. subsalsum.

Keywords: benthic dinoflagellate, biogeography, Bysmatrum granulosum, Bysmatrum gregarium, Bysmatrum subsalsum, eyespot, molecular phylogeny 


\section{$58 \quad$ Introduction}

59 The dinoflagellate genus Bysmatrum Faust \& Steidinger was erected in 1998_(Faust \& Steidinger, 1998). The plate formula of Bysmatrum_is Po, X, 4', 3a, 7", 6C, 4S, 5"',

$6122^{\prime \prime \prime \prime}$ with Bysmatrum subsalsum as type species. The type was initally assigned to

62 Peridinium by Ostenfeld (1908) and transferred later to Scrippsiella Balech ex

63 Loeblich by Steidinger and\& Balech (1977). However, Bysmatrum differs from

64 Scrippsiella mainly in that the anterior intercalary plates $2 \mathrm{a}$ and $3 \mathrm{a}$ are separated by

65 the third apical plate (Faust \& Steidinger 2 1998). Since then, two other Scrippsiella

66 species were transferred to Bysmatrum: Bysmatrum arenicola Horiguchi \& Pienaar

67 (although Scrippsiella arenicola was invalidly published by Horiguchi andㅌ Pienaar,

68 1988a), and B. gregarium (Lombard \& Capon) Horiguchi \& Hoppenrath (= B. caponii,

69 illegitimate). Two-Three other species have been assigned to Bysmatrum: B. granulosum Ten-Hage, Quod, Turquet \& Couté-and ${ }_{2}$ B. teres Murray, Hoppenrath, Larsen \& Patterson and B. austrafrum Dawut, Sym, Suda \& Horiguchi (Ten-Hage et

Biecheler also possesses three intercalary plates with 2a and 3a separated (Biecheler, 1952), and thus might belong to Bysmatrum as well (Murray et al., 2006). In fact,

75 Biecheler (1952, p. 59) regarded Peridinium sociale as a junior synonym of $P$.

76 subsalsum. Useful characteristics to differentiate Bysmatrum species at the

77 interspecific level include overall cell shape, plate ornamentation, cingulum

78 displacement, the position of the nucleus and the shape of the apical pore complex

79 (Horiguchi 1983; Murray et al., 2006).

Formatted: Font: Not Italic

Formatted: Font: Italic

Formatted: Font: Italic

Formatted: Font: Italic

Formatted: Font: Not Italic 
81 Bysmatrum species are considered photosynthetic, benthic dinoflagellates

Formatted: Font: Not Italic

Formatted: Font: Not Italic

Formatted: Font: Italic

Formatted: Font: Not Italic

Formatted: Font: Not Italic

Formatted: Font: Not Italic

Formatted: Font: Not Italic

Formatted: Font: Not Italic

Formatted: Font: Not Italic

101 et al., 2018), and the phylogenetic relationship among Bysmatrum species has not 
102

103

104

Ten-Hage et al., 2001; Jeong et al., 2012; Dawut et al., 2018), but detailed

105

examination using transmission electron microscopy (TEM), which is necessary to

106

characterize the eyespot, has only notbeen carried out on B. austraferum. The eyespot

107 is considered of systematic importance at family level for other dinoflagellates

108 (Lindberg et al., 2005; Moestrup \& Daugbjerg 2007), and its description may help

109 better understand the systematic position of Bysmatrum within the Peridiniales.

110 Information of plate overlap is helpful to identify possible plate homology, thus will

111 contribute to the understanding of the systematic relationship of armoured

112 dinoflagellates (Netzel \& Dürr ${ }_{2}$ 1984).

113 Among the 2000 extant dinoflagellate species, only around $15 \%$ have been

114 related to resting cysts $\left(\operatorname{Head}_{2} 1996\right)$, although many recent studies have described

115 new cyst-motile stage relationships (e.g., Gu et al.,2015a,__2015b). When describing

116 Bysmatrum subsalsum (as Peridinium subsalsum Ostenfeld), Ostenfeld (1908, p. 167)

117 mentioned an ovoid cyst without illustration. Spherical to ovoid cysts were produced

118 by $B$. subsalsum in culture (Gottschling et al, 2012; Anglès et al. 2017) while cysts

119 with the typical plate pattern of B. subsalsum were identified in recent sediments, and

120 survived palynological treatment (Limoges et al, 2015). In addition, unidentified

121 Bysmatrum cells were germinated from ellipsoidal or ovoid cysts found in surface

122 sediment from the Mediterranean lagoons and bays (Satta et al , 2013a, 2013b). The

123 cyst-theca relationship of Bysmatrum has only been established through germination
Formatted: Font: Italic

Formatted: Font: Not Italic

Formatted: Font: Not Italic

Formatted: Font: Not Italic
Formatted: Font: Not Italic

Formatted: Font: Not Italic

Formatted: Font: Not Italic 
125 more Bysmatrum cysts from elsewhere will be helpful to fully understand the

126 diversity within the genus. The geochemical composition of the cyst wall can be

127 studied with the aid of micro-Fourier transform infrared spectroscopy. -Bogus et al. ${ }_{2}$

128 (2014) concluded that cyst walls of autotrophic and heterotrophic species differ in

129 their chemical compositions, thus are useful indicators to infer nutrient strategies.

130 To increase knowledge on the morpho-molecular diversity of Bysmatrum species

131 and to explore their phylogenetic relationships, five strains belonging to three species

132 were established from the South China Sea (B. granulosum, B. gregarium, B.

133 subsalsum), and one strain from the French Atlantic coast (B. subsalsum).

134 Additionally, the morphology of their thecate stages was examined and the molecular

135 phylogeny was inferred with concatenated SSU, LSU rDNA and ITS sequences.

136 Finally, the cyst morphology, cyst wall chemistry and ultrastructure (with a focus on

137 the type of eyespot) were analyzed for B. subsalsum.

\section{Material and methods}

\section{Sample collection and treatment}

141 One liter of surface water samples were collected from the South China Sea (China

142 and Malaysia) using a plastic bottle and concentrated through a $20 \mu \mathrm{m}$ filter, and the

143 upper $5 \mathrm{~cm}$ of sand samples were collected from nearby Rawa Island (Malaysia) by

144 divers. The sand samples were stirred vigorously to detach the epibenthic cells and the 
suspension settled in a composite settling chamber. The settled materials were rinsed

with filtered seawater and transferred into a polycarbonate bottle. Single Bysmatrum

cells were isolated by means of drawn-out Pasteur pipettes under an AE30 inverse

microscope (Motic, Xiamen, China) and established into clonal cultures. Three strains of Bysmatrum were established by isolating a single cell from plankton samples, and two strains from the sand sample (Table 1). Sediment sampling was done using an Ekman grab on 15 and 19 April 2016 in a shallow natural reservoir used for oyster cleansing before commercialization (water depth $1.2-1.5 \mathrm{~m}$ ). The small basin is located north of the community of Gujan-Mestras in the Gironde region of southwestern France. The top $2 \mathrm{~cm}$ of sediment from France were sliced off and stored in the dark at $4{ }^{\circ} \mathrm{C}$ until further treatment. Approximately $5 \mathrm{~g}$ of wet sediment was mixed with $20 \mathrm{~mL}$ of filtered seawater and stirred vigorously to dislodge detrital particles. The settled material was subsequently sieved through $120 \mu \mathrm{m}$ and $10 \mu \mathrm{m}$ filters. Single cysts were isolated with a micropipette under an inverted Eclipse TS100 (Nikon, Tokyo, Japan) microscope and incubated in small containers with $\mathrm{f} / 2-\mathrm{Si}$ medium (Guillard \& Ryther, 1962) at $20^{\circ} \mathrm{C}, 90 \mu \mathrm{E} \cdot \mathrm{m}^{-2} \cdot \mathrm{s}^{-1}$ under a 12:12 h light: dark cycle. Another strain (TIO406) was established in clonal cultures under the same culture conditions (Table 1).

\section{Morphological study of thecate stages and cysts}

Live cells of all strains were examined and photographed using a Zeiss Axio Imager light microscope (Carl Zeiss, Göttingen, Germany) equipped with a Zeiss Axiocam 
HRc digital camera. Cell size of 13-40 cells was measured using Axiovision (4.8.2

167

168

169

170 as described by Tillmann et al., (2009) to strip off the outer cell membrane. Cells were

180 fixed with $2.5 \%$ glutaraldehyde for $3 \mathrm{~h}$ at $8^{\circ} \mathrm{C}$, rinsed with Milli-Q water twice and

version) software at $\times 1000$ magnification. Fluorescence brightener Calcofluor white

(Sigma Adrich, St. Louis, USA) was used to stain the plates following the method of Fritz and \& Triemer (1985). To observe the shape and location of the nucleus, cells were stained with 1:100,000 Sybr Green (Sigma Aldrich, St. Louis, USA) for 1 min, and photographed under the Zeiss fluorescence microscope with a Zeiss-38 filter set (excitation BP 470/40, beam splitter FT 495, emission BP 525/50). Cysts of $B$. subsalsum from Gironde, France with cell contents were photographed and measured using an Olympus DP72 camera mounted on a BX41 microscope with $100 \times$ oil immersion objectives.

For scanning electron microscopy (SEM), mid-exponential batch cultures of all strains were concentrated by a Universal 320 R centrifuge (Hettich-Zentrifugen,

Tuttlingen, Germany) at $850 \mathrm{~g}$ for $10 \mathrm{~min}$ at room temperature. The pellet was treated post-fixed with $1 \% \mathrm{OsO}_{4}$ overnight at $8^{\circ} \mathrm{C}$. The supernatant was removed and the settled cells were transferred to a coverslip coated with poly-L-lysine (molecular weight 70,000-150,000). The cells attached to the cover slip were rinsed in Milli-Q water twice. The samples were then dehydrated in a graded ethanol series $(10 \%, 30 \%$, $50 \%, 70 \%, 90 \%$ and $3 \times$ in $100 \%, 10 \mathrm{~min}$ at each step), critical point dried (K850

Critical Point Dryer, Quorum/Emitech, West Sussex, UK), sputter-coated with gold, and examined with a Zeiss Sigma FE (Carl Zeiss Inc., Oberkochen, Germany) 
188 scanning electron microscope at Xiamen University, China.

189 Single cysts of Bysmatrum subsalsum from Gironde, France were picked from

190 the residue filtered using polycarbonate membrane filters (Millipore, Billerica, MA,

191 USA, GTTP Isopore, $0.22 \mu \mathrm{m}$ pore size), sputter coated with gold, and examined

192 using a FEI Quanta 200 SEM with an electron acceleration of 2.5 to $5 \mathrm{kV}$ at

193 IFREMER (Plouzané, France).

194 The plate overlap was derived for Bysmatrum subsalsum from SEM

195 micrographs. For Vulcanodinium rugosum, SEM micrographs were used that were

196 previously obtained by Nézan and_\& Chomérat (2011). For Parvodinium umbonatum,

197 new SEM micrographs were made for thecae from a plankton sample from a lake to

198 the north of Bergen, Norway $\left(60.47^{\circ} \mathrm{N}, 4.95^{\circ} \mathrm{E}\right)$. Labelling of tabulation follows a

199 modified Kofoid system that recognizes homologs (e.g., Fensome et al., 1993). The

Formatted: Font: Not Italic

200 sulcal plate labelling is according to Balech (1980).

Micro-Fourier infrared spectroscopy

For micro-FTIR analyses, cysts without cell contents of B. subsalsum were isolated-

from palynological residues, and were rinsed three times with organic solvents-

(methanol and dichloromethane) and MilliQ water to remove polar and apolar

compounds. Cysts were placed on a gold-coated mirror, dried, and then analyzed in

reflective mode with 100 scans from $4000-600 \mathrm{~cm}^{-1}$-on a Bruker FT-IR microscope-

Formatted: Widow/Orphan control, Adjust space between Latin and Asian text, Adjust space between Asian text and numbers, Tab stops: $0.34 "$ Left 
The raw spectra $(\mathrm{n}-3)$ were subjected to background subtraction, atmospheric

eorrection and rubberband baseline correction ( 5 iterations).

4

Transmission electron microscopy (TEM) of B. subsalsum

Mid-exponential batch cultures of strains TBBYS02 and TBBYS03 were fixed in

$2.5 \%$ glutaraldehyde in phosphate buffer saline (PBS, $0.1 \mathrm{M}$ at $\mathrm{pH} 7.4$ ) for $1 \mathrm{~h}$,

concentrated by centrifugation and then washed three times with the same PBS for 10 min each. They were post-fixed in $1 \% \mathrm{OsO}_{4}$ overnight at $4{ }^{\circ} \mathrm{C}$ and washed three times with the same PBS for 10 min each. The cells were then dehydrated through a graded ethanol series $(10,30,50,70,95,3 \times$ in $100 \%, 10 \mathrm{~min}$ at each step). The pellet was embedded in Spurr's resin (Spurr, 1969$)$ and sectioned with a Reichert Ultracut E microtome (Leica, Vienna, Austria), mounted on Formvar-coated grids, stained with uranyl acetate and lead citrate, and observed in a JEOL JEM-100 transmission electron microscope (JEOL, Tokyo, Japan).

\section{Micro-Fourier infrared spectroscopy}

For micro-FTIR analyses, cysts without cell contents of B. subsalsum were isolated

from palynological residues, and were rinsed three times with organic solvents

(methanol and dichloromethane) and MilliQ water to remove polar and apolar compounds. Cysts were placed on a gold-coated mirror, dried, and then analyzed in reflective mode with 100 scans from $4000-600 \mathrm{~cm}^{-1}$ on a Hyperion 3000 FT-IR
Formatted: Font: Font color: Auto 
$\underline{\text { microscope (Bruker Optics, Elltingen, Allemagne) with a } 15 \times \text { objective, resulting in a }}$

The total algal DNA of six Bysmatrum strains (Table 1) was extracted from $10 \mathrm{~mL}$ of

were carried out using $1 \times \mathrm{PCR}$ buffer, $50 \mu \mathrm{M}$ dNTP mixture, $0.2 \mu \mathrm{M}$ of each primer,

$10 \mathrm{ng}$ of template genomic DNA, and $1 \mathrm{U}$ of ExTaq DNA Polymerase (Takara, Tokyo,

Japan) in $50 \mu \mathrm{L}$ reactions. The SSU rDNA was amplified using the primers.

PRIMERA/PRIMERB (Medlin et al., 1988). The LSU rDNA was amplified using the primers D1R/28-1483R (Scholin et al., 1994; Daugbjerg et al., 2000). The total

ITS1-5.8S-ITS2 was amplified using ITSA/ITSB primers (Adachi et al., 1996). The

242 thermal cycle procedure was 4 min at $94^{\circ} \mathrm{C}$, followed by 30 cycles of 1 min at $94^{\circ} \mathrm{C}, 1$

Formatted: English (U.K.)

Formatted: Font: Not Italic

Formatted: Font: Not Italic Formatted: Font: Not Italic

Formatted: Font: Not Italic 
Olympus IX70 inverted light microscope, and deposited on a glass slide. Then, it was rinsed into two drops of double distilled water $\left(\mathrm{ddH}_{2} \mathrm{O}\right)$ before transfer to a $0.2 \mathrm{~mL}$

PCR tube containing $3 \mu \mathrm{L}$ of $\mathrm{ddH}_{2} \mathrm{O}$. PCR tubes were stored at $-20^{\circ} \mathrm{C}$ before the direct

PCR amplifications. Each PCR tube was thawed before adding 25 pmol of each primer and $12.5 \mu \mathrm{L}$ of PCR Master Mix 1X (Promega, Madison, WI, USA) containing the Taq DNA polymerase, $\mathrm{dNTPs}, \mathrm{MgCl}_{2}$ and reaction buffers. Three nuclear markers: SSU rDNA, LSU rDNA, internal transcribed spacer region (ITS1-5.8S rDNA-ITS2) were amplified using different cells with several pairs of primers (Table 1 in Nézan et al. 2012). The PCRs were performed in a Mastercycler Personal (Eppendorf, Hamburg, Germany) as follows: one initial denaturation step at $94^{\circ} \mathrm{C}$ for $2 \mathrm{~min}$, followed by 45 cycles at $94^{\circ} \mathrm{C}$ for $30 \mathrm{~s}, 52^{\circ} \mathrm{C}$ for $30 \mathrm{~s}$, and $72^{\circ} \mathrm{C}$ for 4 min, and a final elongation at $72^{\circ} \mathrm{C}$ for $5 \mathrm{~min}$. The PCR products were purified using the Wizard SV Gel and PCR Clean-up system (Promega) according to the manufacturer's recommendations. Then, they were sequenced directly using the ABI PRISM BigDye Terminator Cycle Sequencing Kit (Applied Biosystems, Carlsbad, CA, USA).

Newly obtained sequences were deposited in GenBank with accession numbers

$\underline{\text { MG826100XXXXXX to MG826115XXXXXXand MG826360 to MG826367 (Table }}$ $\underline{\mathrm{S} 1)}$.

\section{Sequence alignment and phylogenetic analysis}

Newly obtained Bysmatrum sequences (nuclear-encoded SSU, partial LSU rDNA and 
270 ITS) were incorporated into a systematically representative set of dinoflagellates

271 available in GenBank. Sequences were aligned using MAFFT v7.110 (Katoh \&

272 Standley 2 2013) online program (http://mafft.cbrc.jp/alignment/server/) with default

273 settings. Alignments were manually checked with BioEdit v. 7.0 .5 (Hall 1999). For

274 Bayesian inference (BI), the program jModelTest (Posada 2008) was used to select

275 the most appropriate model of molecular evolution with Akaike Information Criterion

276 (AIC). Bayesian reconstruction of the data matrix was performed using MrBayes 3.2

277 (Ronquist \& Huelsenbeck, 2003) with the best-fitting substitution model $(G T R+G)$.

278 Four Markov chain Monte Carlo (MCMC) chains ran for 6,000,000 generations,

279 sampling every 100 generations. The first $10 \%$ of burn-in trees were discarded. A

280 majority rule consensus tree was created in order to examine the posterior

281 probabilities of each clade. Maximum likelihood (ML) analyses were conducted with

282 RaxML v7.2.6 (Stamatakis, 2006) on the T-REX web server (Boc et al., 2012) using

283 the model GTR + G. Node support was assessed with 1000 bootstrap replicates.

284 Multiple ITS1-5.8S-ITS2 sequences of Bysmatrum species were aligned using

286 (http://mafft.cbrc.jp/alignment/server/) with default settings. Completed alignments

287 were saved as NEXUS files and imported into PAUP*4b10 software ( $\left.\operatorname{Swofford}_{2} 2002\right)$

288 so that divergence rates could be estimated using simple uncorrected pairwise (p)

289 distance matrices. 
291

292

\section{Results}

\section{Morphology}

\section{Bysmatrum subsalsum}

Cysts of Bysmatrum subsalsum from Gironde, France were 30.0-40.9 $\mu \mathrm{m}$ long (mean $=36.0 \pm 3.4 \mu \mathrm{m}, \mathrm{n}=14)$ and $26.0-34.3 \mu \mathrm{m}$ wide $($ mean $=31.6 \pm 2.8 \mu \mathrm{m}, \mathrm{n}=14)$.

They had a conical epitheca, and a round hypotheca (Fig. 1). The cysts possessed numerous golden granules and a red accumulation body in the sulcal area (Figs 1,2).

Plates were clearly visible and were identical to the thecal plates (Figs 3, 4).

Cells of the strain TIO406 from Gironde, France were 22.7-31.7 $\mu \mathrm{m}$ long (mean $=27.3 \pm 3.2 \mu \mathrm{m}, \mathrm{n}=15)$ and 22.0-29.4 $\mu \mathrm{m}$ wide $($ mean $=23.9 \pm 2.3 \mu \mathrm{m}, \mathrm{n}=15)$.

Under SEM, cysts and vegetative cells of Bysmatrum subsalsum from Gironde,

France showed a plate formula of Po, cp, X, 4', 3a, 7", 6C, 4S, 5'"', $2^{\prime \prime \prime \prime}$. The thecal plates were thick and covered with strong reticulations throughout (Figs 5-10). Thecal pores with a diameter of $0.14-0.28 \mu \mathrm{m}$ were often observed along the plate margins. There were four apical plates. Plate 1' was five-sided and asymmetrical with shorter anterior sutures than the posterior ones (Fig. 5). There were three anterior intercalary plates (1a, 2a and 3a), of which 3a is separated from 2a and 1a. Plate 1a was elongated rectangular whereas plates $2 \mathrm{a}$ and $3 \mathrm{a}$ were hexagonal and pentagonal, respectively (Figs 5-8). The length (of the upper side of 1a) and width (of the right side of 1a) ratio of the French strain TIO406 was $1.2-3.5$ (mean $=1.9 \pm 0.6, \mathrm{n}=16)$. Occasionally, plate 1a was pentagonal ( 3 out of 37 cells). Plate 1" was five-sided and the length of 
312 the upper and low side ratio was $0.63-0.84$ (mean $=0.74 \pm 0.07, \mathrm{n}=14)$. The cingulum

313 was deeply excavated around 3.5-4.2 $\mu \mathrm{m}$ wide (mean $=3.8 \pm 0.3 \mu \mathrm{m}, \mathrm{n}=20)$ and

314 descending ca. its own width, comprising six plates. The first three cingular plates $(\mathrm{C} 1$,

$315 \mathrm{C} 2$ and C3) were similar in size and much smaller than the other three plates (Figs

316 5-7). The apical pore complex (APC) was tear-shaped comprising a pore plate (Po)

317 with a much smaller, round cover plate (cp) and an elongated pentagonal canal plate

318 (X) with thick margins formed by the raised borders of the apical plates (Figs 8, 9).

319 The APC ranged from 7.5 to $8.8 \mu \mathrm{m}$ (mean $=8.2 \pm 0.6, \mathrm{n}=4$ ) in length and from 3.2 to

$3203.5 \mu \mathrm{m}($ mean $=3.4 \pm 0.1, \mathrm{n}=4)$ in width. An apical stalk was sometime observed

321 protruding from the apical pore (Fig. 9). The first postcingular plate (1"') was much

322 smaller than the other plates in the series plates and bore a sulcal list, as well as the

$3235^{\prime \prime \prime}$ (Fig. 10). The first antapical plate (1"'"') was elongated and narrow, displaced to the

324 left, whereas the second antapical plate (2'"') was pentagonal (Fig. 10). The anterior

325 sulcal plate (Sa) and left sulcal (Ss) were elongated and narrow. The right sulcal (Sd)

326 was triangular, with the internal sulcal list (i.s.l.) emerging from its left side. The

327 posterior sulcal plate (Sp) was much wider than long. The left sulcal list (L.s.l.)

328 emerged from the low side of plate 1"' and the right sulcal list (R.s.l.) covered the

329 entire left side of plate 5"' (Fig. 11).

330 The morphologies of Malaysian strains TBBYS02 (Figs 12-16) and TBBYS03

331 (Figs S1-S6) were similar to the French strains (Table 2), although the Malaysian

332 strains lacked a high sulcal list on 5"' (Figs 13, 16, Figs S1, S5) and possessed a more

333 elongated 1a plate. The length and width ratio of the 1a plate were 1.8-4.0 $($ mean $=$ 
$2.5 \pm 0.7, \mathrm{n}=14)$ and $1.8-4.8($ mean $=3.4 \pm 0.9, \mathrm{n}=15)$ for strains TBBYS02 and

335 TBBYS03. The length of the upper and lower side ratio of plate 1 " was $0.69-0.90$

337 TBBYS02 and TBBYS03.

338 Under LM, Malaysian strains showed a lot of banded chloroplasts in the

339 periphery of the cells ('c' in Fig. 17). One pronounced orange eyespot was seen in the

340 sulcal area (Fig. 18). The nucleus was large, elongated and located posteriorly ('n' in

341 Figs 19, 20). TEM confirmed the presence of an eyespot in the sulcal area, and a

342 hypothecal-posterior nucleus as well (Fig. 21). -The chloroplasts had terminal

343 pyrenoids with lamellae intruding the pyrenoid (Fig. 22). The thylakoids were

344 grouped in twos or threes to form lamellae. The eyespot was located within a

345 chloroplast comprising two rows of lipid globules (around 50 each row) with a

346 diameter of 70-110 nm -(Fig. 23). There were-was one row of brick-like crystals

347 enveloped by a vesicle overlying the eyespot, varying in size from $110 \mathrm{~nm}$ long and

$348 \quad 80 \mathrm{~nm}$ wide to $220 \mathrm{~nm}$ long and $140 \mathrm{~nm}$ wide (Fig. 24).

349 Bysmatrum gregarium

350 The cells of strain TIO316 from the South China Sea were 27.2-37.9 $\mu \mathrm{m}$ long (mean

$351=31.0 \pm 3.1 \mu \mathrm{m}, \mathrm{n}=20)$ and $25.5-35.9 \mu \mathrm{m}$ wide $($ mean $=31.1 \pm 2.7 \mu \mathrm{m}, \mathrm{n}=20)$. The

352 cells had a conical epitheca and a rounded hypotheca (Figs 25, 26). Bysmatrum

353 gregarium showed a plate formula of Po, cp, X, 4', 3a, 7", 6C, 4S, 5"', $2^{\prime \prime \prime \prime}$. The thecal

354 plates were thick and covered with strong reticulations. Thecal pores were often 
355 observed on the plates.

356 The first apical plate 1' was five-sided and asymmetrical with the longer anterior

357 sutures than the posterior ones (Fig. 25). There were three anterior intercalary plates

358 (1a, 2a and 3a). Plate 1a was nearly square and 2a and 3a were hexagonal and

359 pentagonal respectively (Figs 26, 27). The length (of the upper side of 1a) and width

360 (of the right side of 1 a) ratio was $0.9-4.0($ mean $=1.9 \pm 1.1, n=9)$. Plate 1 " was

361 five-sided and the length of the upper and low side ratio was $0.45-0.57$ (mean $=0.50$

$362 \pm 0.05, \mathrm{n}=7)$. The cingulum was deeply excavated and descended about 1.5 times its

363 own width, comprising six plates of unequal size (Figs 25-27). The first three

364 cingular plates (C1, C2 and C3) were similar in size and much smaller than the three

365 other plates. The first postcingular plate $\left(1^{\prime \prime \prime}\right)$ was much smaller than other plates in

366 this series (Fig. 28). The first antapical plate ( $\left(1^{\prime \prime \prime \prime}\right)$ was elongated and narrow,

367 displaced to the left, whereas the second antapical plate (2'"') was pentagonal (Fig.

368 28). The apical pore complex comprised a round pore plate (Po), a round cover plate

369 (cp) and an elongated canal plate (X) with a round apical pore located in the middle of

370 the pore plate (Fig. 29).

371 There were four sulcal plates and two sulcal lists. The anterior sulcal plate (Sa)

372 was elongated and narrow. The left sulcal (Ss) was elongated and narrow too. The

373 right sulcal (Sd) was fan-shaped, with a small internal sulcal list (i.s.l.) at its left side.

374 The posterior sulcal plate (Sp) was wider than long (Fig. 30). The left sulcal list (L.s.1.)

375 emerged from the right of plate 1"' (Fig. 28).

376 
Cells of the strain SP004 from the South China Sea were 34.0-42.8 $\mu \mathrm{m}$ long (mean =

379

380

$38.8 \pm 2.5 \mu \mathrm{m}, \mathrm{n}=13)$ and $30.2-42.6 \mu \mathrm{m}$ wide $($ mean $=35.5 \pm 3.8 \mu \mathrm{m}, \mathrm{n}=18)$. The cells had a conical epitheca and a round hypotheca (Fig. 31). Bysmatrum granulosum showed a plate formula of Po, cp, X, 4', 3a, 7", 6C, 4S, 5'", $2^{\prime \prime \prime \prime}$. The thecal plates were thick and covered with small wart-like projections except on the sulcal and cingular plates (Figs 31-36). The apical pore complex was elongated comprising a pore plate $(\mathrm{Po})$ and a narrow canal plate $(\mathrm{X})$ with thickened margins formed by the raised borders of the apical plates (Fig. 34).

The first apical plate 1' was five-sided and asymmetrical with anterior sutures equal in length to the posterior ones (Fig. 31). There were three anterior intercalary plates (1a, 2a and 3a). Plate 1a, 2a and 3a were rectangular, hexagonal and pentagonal respectively (Figs 32, 33)-. The length (of the upper side of 1a) and width (of the right side of $1 \mathrm{a})$ ratio was $1.1-2.3($ mean $=1.5 \pm 0.4, \mathrm{n}=12)$. Plate 1 " was five-sided and the length of the upper and low side ratio was $0.65-0.85$ (mean $=0.74 \pm 0.05, n=12)$. The cingulum was deeply excavated and descended about 1.5 times of own width, comprising six plates of unequal size (Figs 31,33$)$. The first three cingular plates $(\mathrm{C} 1$, $\mathrm{C} 2$ and C3) were similar in size and much smaller than the three other plates. The first postcingular plate $\left(1^{\prime \prime \prime}\right)$ was smaller than other plates in this series (Fig. 35$)$. The first antapical plate $\left(1^{\prime \prime \prime \prime}\right)$ was wider than long, displaced to the left, whereas the second antapical plate (2'"') was five-sided and slightly larger (Fig. 35).

There were four sulcal plates and two sulcal lists. The anterior sulcal plate ( $\mathrm{Sa})$ 
399 was triangular and the left sulcal (Ss) and right sulcal (Sd) were elongated and narrow.

400 A small internal sulcal list (i.s.1.) was located at the left side of $\mathrm{Sd}$. The posterior

401 sulcal plate (Sp) was wider than long (Fig. 36). The left sulcal list (L.s.l.) emerged

402 from the right side of plate $1^{\prime \prime \prime}$ (Fig. 35).

403 Cells of the strain A10-P14-R2 from the South China Sea were 37.7-55.4 $\mu \mathrm{m}$

404 long $($ mean $=46.2 \pm 4.2 \mu \mathrm{m}, \mathrm{n}=40)$ and $34.8-50.3 \mu \mathrm{m}$ wide $($ mean $=43.3 \pm 4.1 \mu \mathrm{m}$,

$405 \mathrm{n}=40$ ). The cells shared similar morphology with those of strain SP004 (Figs S7-S12,

406 table 2).

407

408

409

Epithecal plate overlap in Bysmatrum, Parvodinium and Vulcanodinium

410 The epithecal plate overlap of all studied Bysmatrum species is identical and is

411 exemplified in B. subsalsum (Fig. 37). The epithecal plate overlap of Vulcanodinium

412 Nézan \& Chomérat, Parvodinium Carty and Bysmatrum is characteristic for each

413 genus (Figs 38, 39). These morphological differences are concordant to the genetic

414 distances between the genera (Fig. 40).

415

MicroFTIR analysis of cysts of Bysmatrum subsalsum from France $\underline{\text { French }}$

416 Atlantic

417 The geochemical analysis of the cyst walls of three specimens (M3S11, M3S12,

418 M10S3) was illustrated in Fig. 41. There were absorptions for $\mathrm{OH}$ stretching centered

419 at $\sim 3300 \mathrm{~cm}^{-1}$ as well as aliphatic $\mathrm{CH}$ stretching $\left(2725 \& 2850 \mathrm{~cm}^{-1}\right)$ and bending 
$420\left(1420 \& 1370 \mathrm{~cm}^{-1}\right)$ (not delineated in Fig. 41). There were also absorptions that are

421

422

423

424

characteristic for polysaccharides (Pandey 1999; Kačuráková \& Wilson 2001), including $1640 \mathrm{~cm}^{-1}$ ( $\mathrm{C}=\mathrm{O}$ stretching), $1160 \mathrm{~cm}^{-1}$ (C-O-C asymmetric vibration), 1115 $\mathrm{cm}^{-1}$ (glucose ring stretching) and C-O stretching absorptions at $1060 \mathrm{~cm}^{-1}, 1040 \mathrm{~cm}^{-1}$ and $1030 \mathrm{~cm}^{-1}$.

Overall, M3S11 and M10S3 showed the greatest similarity, including a shoulder at $1540 \mathrm{~cm}^{-1}$ that could suggest either extracellular contamination or amide groups within the cyst wall; however, there were no other clear absorptions for proteinaceous material (see contamination discussion in Mertens et al., 2015). The M3S12 spectrum is different in that it exhibits a shoulder at $1640 \mathrm{~cm}^{-1}$ and a band at $1590 \mathrm{~cm}^{-1}$ that reflect $\mathrm{C}=\mathrm{O}$ and $\mathrm{C}=\mathrm{C}$ stretching, respectively

\section{Molecular analysis and phylogeny}

The genetic distance based on ITS1-5.8S-ITS2 sequences among Bysmatrum morphospecies ranged from 0.34 to 0.47 and those genetic distances at intraspecific level were 0.15 (B. gregarium and B. granulosum) and 0.09 to 0.41 (B. subsalsum) (Table 3).

The maximum likelihood (ML) and Bayesian inference (BI) analysis based on combined SSU rDNA, partial LSU rDNA and ITS sequences yielded similar phylogenetic trees. The BI tree was illustrated in Fig. 40. The genus Bysmatrum was monophyletic with maximal support. It was clearly nested within the Peridiniales and formed a clade with Parvodinium, Peridiniopsis borgei, Palatinus apiculatus, 
Vulcanodinium rugosum, Peridinium cintum and Protoperidinium with

442 support (68/0.71). Bysmatrum subsalsum consisted of two well resolved subclades.

443 One subclade comprised strains from the Mediterranean Sea (refered to ribotype A)

444 and the other included strains from Malaysia and French Atlantic (refered to ribotype

B). BysmatrumB. gregarium and B. granulosum grouped together with strong ML support (100), but low posterior probability (0.-70).

Discussion

\section{Morphology and biogeography}

451 The strains of B. subsalsum from French Atlantic were characterized by the separation

452 of plates $2 \mathrm{a}$ and $3 \mathrm{a}$ and an elongated rectangular 1a plate, thus fitting the original

453 descriptions, especially the presence of three sulcal lists (Ostenfeld ${ }_{2}$ 1908, fig. 50).

454

455

456

457

458

459

460 and width of 1a plate might be a useful indicator to differentiate $B$. subsalsum strains,

461 but the ratio of length of upper and lower side of 2" plate appears rather conservative
Formatted: Font: Not Italic

Formatted: Font: Not Italic 
among these strains (Table 2). A significant correlation between APC length and total cell length was reported in B. subsalsum from the Mediterranean Sea (Anglès et al., 2017), and confirmed in the Malaysian and French strains as well. Because of the morphological similarity between our strains and strains from elsewhere, we identified them as B. subsalsum.

Bysmatrum subsalsum has a worldwide distribution, recorded in the Aral Sea

(Ostenfeld, 1908), the Caribbean (Faust \& Steidinger, 1998), the Gulf of Mexico (Limoges et al., 2015), the Mediterranean Sea (Gottschling et al.,2012; Anglès et al., 2017), Argentina (Balech, 1964, as P. subsalsum), Japan (Horiguchi, 1983), and in the South China Sea and French Atlantic as reported here.

Bysmatrum subsalsum is morphologically close to Peridinium sociale (Henneguy)

Biecheler as described by Biecheler (1952), but our strains are much smaller and have less cingulum displacement (1.0 versus 1.5 cingular widths). However, the Mediterranean B. subsalsum strains can have a cingulum displacement from 1.0 to 1.5 and have a large variability in cell size (Anglès et al., 2017). Therefore, the species reported by Biecheler (1952) might be conspecific with B. subsalsum. However, whether B. subsalsum is a junior synonnym of Peridinium sociale remains to determined since Henneguy (1890) described Glenodinium sociale without giving information about the tabulation.

An apical stalk emerged from the apical pore of B. subsalsum (Fig. 9), and has been reported for B. arenicola and B. gregarium as well, suggesting that this is a common feature for the genus, possibly related with their epibenthic life stage. Mucus
Formatted: Font: Not Italic

Formatted: Font: Not Italic 


\section{excreted from the apical stalk was observed in B. subsalsum and B. granulosum,}

489 thecal plates, as also reported in those from Gulf of Mexico and Mediterranean Sea (Limoges et al, 2015; Anglès et al. 2017). The geochemical analysis of the cyst walls

491 of three specimens (M3S11, M3S12, M10S3; Fig. 41) showed overall consistency

492 with other extant dinoflagellate cysts analyzed from surface sediments (e.g., Bogus et

494 could indicate aromatic bonds are present in this spectrum, similar to Pyrodinium bahamense (Mertens et al , 2015). The variability in the three specimens could reflect

496 intraspecific differences in cysts even from the same location. The spectra of $B$.
Formatted: Font: Not Italic

Formatted: Font: Not Italic
Formatted: Font: Not Italic

Formatted: Font: Not Italic

Formatted: Font: Not Italic 
Lombard and $\underline{\&}$ Capon (1971) described a new thecate dinoflagellate isolated from

509 Capon. After the illegitimate renaming of $P$. gregarium as Scrippsiella caponii by

510 Horiguchi and \& Pienaar (1988a), and the therefore illegitimate transfer to Bysmatrum caponii by Faust and \& Steidinger (1998), the correct name for this species is now

512 considered to be Bysmatrum gregarium (see Hoppenrath et al., 2014, p. 65 for further

513 details). The Chinese strain TIO316 generally fits the original description of $B$.

514 gregarium but differs in the relative size of C2 and C3 (similar size of C2 and C3 in

515 TIO316 versus half length of C3 in the type material) (Horiguchi \& Pienaar, 1988a).

516 Strain TIO316 is morphologically indistinguishable from the Korean strains described

517 by Jeong et al., (2012) which also have plates C2 and C3 of similar size. Bysmatrum

518 gregarium is morphologically very close to B. subsalsum (Anglès et al., 2017),

519 however, the ratio of length of upper and lower side of 2 " plate appears useful to

520 differentiate them ( 0.5 vs 0.7 , see table 2$)$. Additionally, the ratio of total cell length

521 and APC length can reach 5.0 in the B. gregarium strain TIO316, much larger than

522 those of B. subsalsum strains (less than 4.0).

523 Bysmatrum gregarium has been reported in southern California, western Korea 524 (Jeong et al., 2012), Mexican Caribbean (Almazán-Becerril et al., 2015), the island of 
527 Bysmatrum granulosum

528 The Malaysian strains SP004 and A10-P14-R2 of Bysmatrum granulosum fit the

529 original description by wart-like projections on the thecal surface. BysmatrumB.

530 granulosum was described from sediment and coral samples collected from Reunion

531 Island, South West Indian Ocean (Ten-Hage et al., 2001), and later found in Sabah,

532 Malaysia (Mohammad-Noor et al., 2007) and Mexican Caribbean (Almazán-Becerril

Formatted: Font: Not Italic

533 et al., 2015). In this study, it was found in Rawa Island and Perhentian Island, thus

534 extends its distribution to Malay Peninsula. Our strains were also isolated from coral

535 reef debris, thus support the idea that this species is always associated with corals

536 (Ten-Hage et al., 2001).

537 Eyespot structure of Bysmatrum subsalsum from Malaysia

538

539

540

541

542

543

544

545

546

547

548
Moestrup and $\underline{\&}$ Daugbjerg (2007) reviewed five different types of eyespot in dinoflagellates, excluding the complex ocelloid of the Warnowiaceae (Greuet, 1987):

(1) type A, characterized by one to several layers of opaque globules inside a

chloroplast; (2) type B, a vesicle containing crystal-like units overlying an eyespot

type A-like chloroplast; (3) type C, layers of opaque lipid globules not bounded by a

membrane; (4) type D, layers of opaque globules inside a reduced bounded by

envelopes not connected to-chloroplast; and (5) type E, several layers of crystal-like

units contained in a vesicle. Craveiro et al., (2010) reported a new type of eyespot (as

type F), characterized by a single layer of vesicle-contained crystal-like units

overlying layers of more or less fused globules not bounded by membranes. The

eyespot of B. subsalsum is located within the chloroplast and consists of two rows of 
549 lipid globules with overlying brick-like crystals, thus was identified as type B eyespot,

550 as also reported in Borghiella dodgei (Moestrup et al.,2008) and Baldinia

551 anauniensis (Hansen et al, 2007).

552 A prominent eyespot has been previously reported in B. subsalsum (Faust \& 553 Steidinger ${ }_{2}$ 1998; Anglès et al. 2017), B. granulosum (Ten-Hage et al..,2001) and $B$.

554 gregarium (Jeong et al., 2012) and is confirmed in B. subsalsum here. However, it 555 was not described for B. arenicola (Horiguchi \& Pienaar ${ }_{2}$ 1988b) and B. teres (Murray to suggest that Bysmatrum is closer to Gonyaucales. Later however, Jeong et al,

568 (2012) reported that Bysmatrum gregarium is close to Protoperidinium and

et al., 2006). A type A eyespot was reported in B. austraferum (Dawut et al.. 2018), and in species of Peridiniales such as Scrippsiella trochoidea (Craveiro et al., 2011),

Palatinus apiculatus (Craveiro et al, 2009), Naiadinium polonicum (Craveiro et al., 2015), and Peridinium willei (Moestrup \& Daugbjerg, 2007), suggesting that Bysmatrum is systematically distant from Thoracosphaeraceae but close to Peridiniaceae and Peridiniopsidaceae (Fig. 40).

\section{Phylogeny and genetic differentiation}

The phylogenetic position of Bysmatrum was first reported by Gottschling et al., (2012) using concatenated SSU, ITS and LSU sequences. In their trees, Bysmatrum subsalsum appears distant from other Peridiniales, and led Gottschling et al
Formatted: Font: Not Italic

Formatted: Font: Not Italic

Formatted: Font color: Black

Formatted: Font: Not Italic, Font color: Black

Formatted: Font color: Black

Formatted: Font: Italic

Formatted: Font: Not Italic

Formatted: Font: Not Italic

Formatted: Font: Not Italic

Formatted: Font: Not Italic

Formatted: Font: Not Italic

Formatted: Font: Not Italic

Formatted: Font: Not Italic 
the Peridiniales (Anglès et al., 2017) and a close relationship between Bysmatrum and

572 the freshwater planktonic genus Parvodinium. These two genera share the separation of anterior intercalary plates (Carty $\left.{ }_{2} 2008\right)$, although Parvodinium only has two

574 anterior intercalary plates in contrast to the three found in Bysmatrum (Hansen \&

576 Peridiniopsidaceae together with Peridiniopsis Bourrelly and Palatinus Craveiro,

Calado, Daugbjerg \& Moestrup (Gottschling et al., 2017). An eyespot is probably detailed study has not been carried out and

\section{0 research.}

$581 \quad$ The close relationship between Bysmatrum and Vulcanodinium is not surprising

582 because of their similarity in shape and plate pattern and thick, reticulate plates. The

583 major difference is the separation of plates 2a and 3a in Bysmatrum, which does not

584 occur in Vulcanodinium (Nézan \& Chomérat, 2011). In addition, Bysmatrum

585 subsalsum strain TBBYS02 is not able to produce pinnatoxin (Krock B. personal

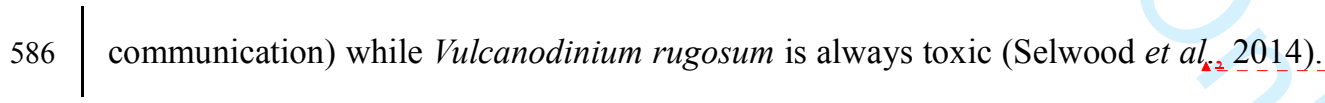

Formatted: Font: Not Italic

587 The ITS based genetic distances at intraspecific level in B. subsalsum reached 0.4,

588 similar to those between the different sequenced Bysmatrum species (Table 3) and

589 much greater than a threshold of 0.04 to delimit species based on ITS based genetic

590 distances (Litaker et al., 2007), supporting the idea that cryptic diversity is hidden in

591 B. subsalsum (Anglès et al., 2017). It is worth noting that two Malaysian strains of

592 Bysmatrum subsalsum were recovered from a single water sample and showed large 
593 genetic differentiation, as also reported in the two B. granulosum strains collected in

594 neighbouring locations. Whether such genetic differentiations also occurs in other

595 Bysmatrum species remains to be confirmed.

596

\section{Acknowledgements}

598 We thank two anonymous reviewers for constructive suggestions that greatly

599 improved the manuscript. This work was supported by the National Key Research and 600 Development $\underline{\text { Program of China (2016YFE0202100), National Natural Science }}$

601 Foundation of China (41676117) and China-ASEAN Maritime Cooperation Fund. N.

602 Gayet is acknowledged for critical-point drying of the samples for SEM. Claire

603 Meteigner and Myriam Rumebe are thanked for sediment sampling in France. Data on

604 Malaysian strains was part of research dissertation of ZFL.

605

\section{References}

607 Adachi, M., Sako, Y. \& Ishida Y. (1996). Analysis of Alexandrium (Dinophyceae) species using sequences of the 5.8S ribosomal DNA and internal transcribed spacer regions. Journal of Phycology, 32: 424-432.

Almazán-Becerril, A., Escobar-Morales, S., Rosiles-González, G. \& Valadez, F. (2015). Benthic-epiphytic dinoflagellates from the northern portion of the Mesoamerican Reef System. Botanica Marina, 58: 115-128.

Anglès, S., Reñé, A., Garcés, E., Lugliè, A., Sechi, N., Camp, J. \& Satta, C.T. (2017). Morphological and molecular characterization of Bysmatrum subsalsum 
615

616

617

618

619

620

621

622

623

624

625

626

627

628

629

630

631

632

633 Carty, S. (2008). Parvodinium gen. nov. for the Umbonatum group of Peridinium

634

635

636

(Dinophyceae) from the western Mediterranean Sea reveals the existence of cryptic species. Journal of Phycology, 53: 833-847.

Balech, E. (1964). Tercera contribucion al conocimiento del genero Peridinium. Museo Argentino de ciencias naturales 'Bernadino Rivadavia'e Instituto nacional de investigacion de las ciencias naturales, Revista, Hydrobiologia, 4: $179-195$.

Balech, E. (1980). On the thecal morphology of dinoflagellates with special emphasis on circular and sulcal plates. Anales del Centro de Ciencias del Mar y Limnologia, Universidad Nacional Autonomia de Mexico, 7: 57-68.

Biecheler, B. (1952). Recherches sur les Peridiniens. Bull. Biol. de la France et de la Belgique, 36: 1-147.

Boc, A., Diallo, A.B. \& Makarenkov, V. (2012). T-REX: a web server for inferring, validating and visualizing phylogenetic trees and networks. Nucleic Acids Research, 40: W573-W579.

Bogus, K., Mertens, K.N., Lauwaert, J., Harding, I.C., Vrielinck, H., Zonneveld, K.A. \& Versteegh, G.J. (2014). Differences in the chemical composition of organic-walled dinoflagellate resting cysts from phototrophic and heterotrophic dinoflagellates. Journal of Phycology, 50: 254-266. (Dinophyceae). Ohio Journal of Science, 108: 103-107.

Craveiro, S., Calado, A.J., Daugbjerg, N. \& Moestrup, Ø. (2009). Ultrastructure and LSU rDNA-based revision of Peridinium group palatinum (Dinophyceae) with 
the description of Palatinus gen. nov. Journal of Phycology, 45: 1175-1194.

638

639

640
Craveiro, S.C., Moestrup, Ø., Daugbjerg, N. \& Calado, A.J. (2010). Ultrastructure and large subunit rDNA $\square$ based phylogeny of Sphaerodinium cracoviense, an unusual freshwater dinoflagellate with a novel type of eyespot. Journal of Eukaryotic Microbiology, 57: 568-585.

Craveiro, S.C., Calado, A.J., Daugbjerg, N., Hansen, G. \& Moestrup, Ø. (2011). Ultrastructure and LSU rDNA-based Phylogeny of Peridinium lomnickii and Description of Chimonodinium gen. nov. (Dinophyceae). Protist, 162: $590-615$.

Craveiro, S.C., Daugbjerg, N., Moestrup, Ø. \& Calado, A.J. (2015). Fine-structural characterization and phylogeny of Peridinium polonicum, type species of the recently described genus Naiadinium (Dinophyceae). European Journal of Protistology, 51: 259-279.

Daugbjerg, N., Hansen, G., Larsen, J. \& Moestrup, Ø. (2000). Phylogeny of some of the major genera of dinoflagellates based on ultrastructure and partial LSU rDNA sequence data, including the erection of three new genera of unarmoured dinoflagellates. Phycologia, 39: 302-317.

Dawut, M., Sym, S.D., Suda, S. \& Horiguchi, T. (2018). Bysmatrum austrafrum sp. nov. (Dinophyceae), a novel tidal pool dinoflagellate from South Africa. Phycologia 57: 169-178.

Faust, M.A. (1996). Morphology and ecology of the marine benthic dinoflagellate

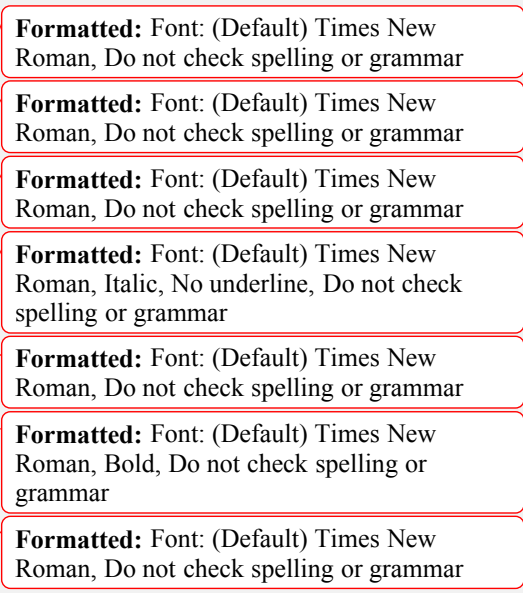

Formatted: Font: (Default) Times New

Formatted: Font: (Default) Times New

Roman, Do not check spelling or gramma

Formatted: Font: (Default) Times New

Roman, Do not check spelling or gramma

Roman, Italic, No underline, Do not check spelling or grammar

Formatted: Font: (Default) Times New Roman, Do not check spelling or gramma

imes New grammar

Roman, Do not check spelling or gramma 
Scrippsiella subsalsa (Dinophyceae). Journal of Phycology, 32: 669-675.

Faust, M.A. \& Steidinger, K.A. (1998). Bysmatrum gen. nov. (Dinophyceae) and three new combinations for benthic scrippsielloid species. Phycologia, 37: 47-52.

Fensome, R.A., Taylor, F.J.R., Norris, G., Sarjeant, W.A.S., Wharton, D.I. \& Williams, G.L. (1993). A classification of fossil and living dinoflagellates. Micropaleontology Special Publication, 7: 1-245.

Fritz, L. \& Triemer, R. (1985). A rapid simple technique utilizing calcofluor white $\mathrm{M} 2 \mathrm{R}$ for the visualization of dinoflagellate thecal plates. Journal of Phycology, 21: 662-664.

Greuet, C. (1987). Complex organelles. In The Biology of Dinoflagellates (Taylor, F. J. R., editor), 117-142. Blackwell Scientific Publications, Oxford.

Gottschling, M., Soehner, S., Zinssmeister, C., John, U., Plötner, J., Schweikert, M., Aligizaki, K. \& Elbrächter, M. (2012). Delimitation of the Thoracosphaeraceae (Dinophyceae), including the calcareous dinoflagellates, based on large amounts of Ribosomal RNA sequence data. Protist, 163: 15-24.

Gottschling, M., Kretschmann, J. \& Čalasan, A.Ž. (2017). Description of Peridiniopsidaceae, fam. nov. (Peridiniales, Dinophyceae). Phytotaxa, 299: $293-296$.

Gu, H., Luo, Z., Mertens, K.N., Price, A.M., Turner, R.E. \& Rabalais, N.N. (2015a). Cyst $\square$ motile stage relationship, morphology, ultrastructure, and molecular phylogeny of the gymnodinioid dinoflagellate Barrufeta resplendens comb. nov., formerly known as Gyrodinium resplendens, isolated from the Gulf of 
Mexico. Journal of Phycology, 51: 990-999.

682

Gu, H., Liu, T. \& Mertens, K. (2015b). Cyst-theca relationship and phylogenetic

683

684

685

686

687

688

689

690

691

692

693

694

695

696

697

698

699

700

701

702 positions of Protoperidinium (Peridiniales, Dinophyceae) species of the sections Conica and Tabulata, with description of Protoperidinium shanghaiense sp. nov. Phycologia, 54: 49-66.

Gurdebeke, P.R., Mertens, K.N., Bogus, K., Marret, F., Chomérat, N., Vrielinck, H., Louwye, S. (accepted). Taxonomic reinvestigation and geochemical eharacterization of Reid's (1974) species of Spiniferites from holotype and topotype material. Palynology.

Hall, T.A. (1999). BioEdit: a user-friendly biological sequence alignment editor and analysis program for Windows 95/98/NT. pp. 95-98.

Hansen, G., Daugbjerg, N. \& Henriksen, P. (2007). Baldinia anauniensis gen. et sp. nov.: a "new" dinoflagellate from lake Tovel, N. Italy. Phycologia, 46: $86-108$.

Hansen, G. \& Flaim, G. (2007). Dinoflagellates of the Trentino Province, Italy. Journal of Limnology, 66: 107-141.

Head, M.J. (1996) Modern dinoflagellate cysts and their biological affinities. In Palynology: principles and applications (Jansonius, J. \& McGregor, D.C., editors), 1197-1248. American Association of Stratigraphic Palynologists Foundation, Dallas.

Henneguy, M.F. (1890). Contributions a l'étude de la faune des marais salants.

Compte Rendu Societé Biologique, 9: 625-627.

Formatted: Font: Bold 
703

Hoppenrath, M., Murray, S. A., Chomérat, N., \& Horiguchi, T. (2014). Marine benthic dinoflagellates - unveiling their worldwide biodiversity. $\underline{\text { Kleine }}$ Senckenberg-Reihe 54, Schweizerbart Science, Stuttgart.

Horiguchi, T. (1983). Life History and Taxonomy of Benthic Dinoflagellates (Pyrrophyta). PhD thesis. University of Tsukuba, Tsukuba, Japan. 142 pp.

Horiguchi, T. \& Pienaar, R.N. (1988a). A redescription of the tidal pool dinoflagellate Peridinium gregarium based on re-examination of the type material. European Journal of Phycology, 23: 33-39.

Horiguchi, T. \& Pienaar, R. (1988b). Ultrastructure of a new sand-dwelling dinoflagellate, Scrippsiella arenicola sp. nov. Journal of Phycology, 24: $426-438$.

Jeong, H.J., Jang, S.H., Kang, N.S., Yoo, Y.D., Kim, M.J., Lee, K.H., Yoon, E.Y., Potvin, É., Hwang, Y.J. \& Kim, J.I. (2012). Molecular characterization and morphology of the photosynthetic dinoflagellate Bysmatrum caponii from two solar saltons in western Korea. Ocean Science Journal, 47: 1-18.

Kačuráková, M. \& Wilson, R H. (2001). Developments in mid-infrared FT-IR spectroscopy of selected carbohydrates. Carbohydrate Polymers, 44: 291-303.

Katoh, K. \& Standley, D.M. (2013). MAFFT Multiple Sequence Alignment Software Version 7: Improvements in Performance and Usability. Molecular Biology and Evolution, 30: 772-780.

Limoges, A., Mertens, K.N., Ruíz $\square$ Fernández ,A.C. \& Vernal, A. (2015). First report 
of fossilized cysts produced by the benthic Bysmatrum subsalsum

(Dinophyceae) from a shallow Mexican lagoon in the Gulf of Mexico. Journal of Phycology, 51: 211-215.

Lindberg, K., Moestrup, Ø. \& Daugbjerg, N. (2005). Studies on woloszynskioid dinoflagellates I: Woloszynskia coronata re-examined using light and electron microscopy and partial LSU rDNA sequences, with description of Tovellia gen. nov. and Jadwigia gen. nov. (Tovelliaceae fam. nov.). Phycologia, 44: 416-440.

Litaker, W.R., Vandersea, M.W., Kibler, S.R., Reece, K.S., Stokes, N.A., Lutzoni, F.M., Yonish, B.A., West, M.A., Black, M.N.D. \& Tester, P.A. (2007). Recognizing dinoflagellate species using ITS rDNA sequences. Journal of Phycology, 43: 344-355.

Lombard, E.H. \& Capon, B. (1971). Peridinium gregarium, a new species of dinoflagellate. Journal of Phycology, 7: 184-187.

Medlin, L., Elwood, H.J., Stickel, S. \& Sogin, M.L. (1988). The characterization of enzymatically amplified eukaryotic 16S-like rRNA-coding regions. Gene, 71: 491-499.

Mertens, K.N., Wolny, J., Carbonell-Moore, C., Bogus, K., Ellegaard, M., Limoges, A., de Vernal, A., Gurdebeke, P., Omura, T. \& Al-Muftah, A. (2015). Taxonomic re-examination of the toxic armored dinoflagellate Pyrodinium bahamense Plate 1906: Can morphology or LSU sequencing separate $P$. bahamense var. compressum from var. bahamense? Harmful Algae, 41: 1-24. 
Moestrup, Ø. \& Daugbjerg, N. (2007). On dinoflagellate phylogeny and classification. In Unravelling the algae: the past, present, and future of algal systematics

(Brodie, J. \& Lewis J., editors), 215-230. The Systematics Association Special Volume Series, CRC Press, Boca Raton, Florida.

Moestrup, Ø., Hansen, G. \& Daugbjerg, N. (2008). Studies on woloszynskioid dinoflagellates III: on the ultrastructure and phylogeny of Borghiella dodgei gen. et sp. nov., a cold-water species from Lake Tovel, N. Italy, and on $B$. tenuissima comb. nov. (syn. Woloszynskia tenuissima). Phycologia, 47: 54-78.

Mohammad-Noor, N., Daugbjerg, N., Moestrup, Ø. \& Anton, A. (2007). Marine epibenthic dinoflagellates from Malaysia--A study of live cultures and preserved samples based on light and scanning electron microscopy. Nordic Journal of Botany, 24: 629-690.

Murray, S., Hoppenrath, M., Larsen, J. \& Patterson, D.J. (2006). Bysmatrum teres sp. nov., a new sand-dwelling dinoflagellate from north-western Australia. Phycologia, 45: 161-167.

Nézan, E. \& Chomérat, N. (2011). Vulcanodinium rugosum gen. et sp. nov. (Dinophyceae), un nouveau dinoflagellé marin de la côte méditerranéenne française. Cryptogamie-Algologie, 32: 3-18.

Nézan, E., Tillmann, U., Bilien, G., Boulben, S., Chèze, K., Zentz, F., Salas, R. \& Chomérat, N. (2012). Taxonomic revision of the dinoflagellate Amphidoma caudata: transfer to the genus Azadinium (Dinophyceae) and proposal of two varieties, based on morphological and molecular phylogenetic analyses. 
770 Netzel, H. \& Dürr G. (1984). Dinoflagellate cell cortex. In Dinoflagellates (Spector,

Pandey, K K. (1999). A study of chemical structure of soft and hardwood and wood

\section{Satta, C. T., Anglès, S., Lugliè, A., Guillén, J., Sechi, N., Camp, J. \& Garcés, E.} (2013b). Studies on dinoflagellate cyst assemblages in two estuarine

Formatted: Indent: Left: 0", Hanging: 0.5", Tab stops: Not at $0.51 "$

Posada, D. (2008). jModelTest: phylogenetic model averaging. Molecular Biology and Evolution, 25: 1253-1256.

Ronquist, F. \& Huelsenbeck, J.P. (2003). MrBayes 3: Bayesian phylogenetic inference under mixed models. Bioinformatics, 19: 1572-1574.

Satta, C.T., Anglès, S., Garcés, E., Sechi, N., Pulina, S., Padedda, B.M., Stacca, D. \& Lugliè, A. (2013a). Dinoflagellate cyst assemblages in surface sediments from three shallow Mediterranean lagoons (Sardinia, North Western Mediterranean Sea). Estuaries and Coasts, 37: 1-18. 
Mediterranean bays: A useful tool for the discovery and mapping of harmful algal species. Harmful Algae, 24: 65-79.

Formatted: Indent: Left: 0", Hanging: 0.5", Line spacing: Double, Adjust space between Latin and Asian text, Adjust space between Asian text and numbers
795 Scholin, C.A., Herzog, M., Sogin, M. \& Anderson, D.M. (1994). Identification of group- and strain-specific genetic markers for globally distributed Alexandrium (Dinophyceae). II. Sequence analysis of a fragment of the LSU rRNA gene. Journal of Phycology, 30: 999-1011.

Selwood, A. I., Wilkins, A.L., Munday, R., Gu, H., Smith, K.F., Rhodes, L.L. \& Rise, F. (2014). Pinnatoxin H: a new pinnatoxin analogue from a South China Sea Vulcanodinium rugosum isolate. Tetrahedron Letters, 55: 5508-5510.

Spurr, A.R. (1969). A low-viscosity epoxy resin embedding medium for electron microscopy. Journal of Ultrastructure Research, 26: 31-43.

Stamatakis, A. (2006). RAxML-VI-HPC: maximum likelihood-based phylogenetic analyses with thousands of taxa and mixed models. Bioinformatics, 22: $2688-2690$.

Steidinger, K. A.; \& BALECH, E. (1977). Scrippsiella subsalsa (Ostenfeld) comb nov. (Dinophyceae) with a discussion on scrippsiellascrippsiella. Phycologia, 16: $69-73$.

Swofford, D.L. (2002). PAUP*. Phylogenetic analysis using parsimony (* and other methods), version 4. Sinauer Associates, Sunderland, Massachusetts.

Ten-Hage, L., Quod, J., Turquet, J. \& Couté, A. (2001). Bysmatrum granulosum sp. 
nov. a new benthic dinoflagellate from the southwestern India sea. European Journal of Phycology, 36: 129-135.

816 spinosum gen. et sp. nov. (Dinophyceae) identified as a primary producer of azaspiracid toxins. European Journal of Phycology, 44: 63-79.

\section{Figure captions}

Figs 1-4. Light micrographs of live cysts of Bysmatrum subsalsum from France. Fig.

1. Ventral view in mid-focus showing numerous granules, a red accumulation body and the apical stalk. Fig. 2. Dorsal view showing numerous granules, a red accumulation body. Fig. 3. Ventral view showing the cingulum displacement. Fig. 4. Dorsal view showing the plates. Scale bars $=10 \mu \mathrm{m}$.

Figs 5-10. Scanning electron micrographs of cysts of French Bysmatrum subsalsum.

Fig. 5. Ventral view showing the first apical plate and cingulum displacement.

Fig. 6. Left lateral view showing the first three cingular plates (C1, C2 and C3).

Fig.7. Dorsal view showing the separation of plates 2a and 3a. Fig. 8. Apical view showing four apical plates $\left(1^{\prime}-4^{\prime}\right)$, three anterior intercalary $(1 \mathrm{a}, 2 \mathrm{a}$ and 3a) plates and seven precingular plates $\left(1^{\prime \prime}-7^{\prime \prime}\right)$. Fig. 9. Apical pore complex showing the apical stalk emerging from the apical pore, pore plate $(\mathrm{Po})$ and the 
narrow canal plate (X). Fig. 10. Antapical view showing five postcingular plates $\left(1^{\prime \prime \prime}-5^{\prime \prime \prime}\right)$ and two antapical plates $\left(1^{\prime \prime \prime \prime}, 2^{\prime \prime \prime \prime}\right)$ of unequal size. Scale bars $=10$ $\mu \mathrm{m}$.

Figs 11-16. Scanning electron micrographs of vegetative cells of Bysmatrum subsalsum from French strain TIO406 (11) and Malaysian strain TBBYS02 (12-16). Fig. 11. The sulcus showing the anterior sulcal plate (Sa), left sulcal plate (Ss), right sulcal plate (Sd), posterior sulcal plate (Sp), the right sulcal list (R.s.1.), the left sulcal list (L.s.l.) and the internal sulcal list (i.s.l.). Fig. 12. Apical view showing four apical plates $\left(1^{\prime}-4^{\prime}\right)$, three anterior intercalary $(1 \mathrm{a}$, 2a and 3a) plates and seven precingular plates $\left(1^{\prime \prime}-7^{\prime \prime}\right)$. Fig. 13. Antapical view showing five postcingular plates $\left(1^{\prime \prime \prime}-5^{\prime \prime \prime}\right)$ and left and internal sulcal lists. Fig. 14. Right lateral view showing the first apical plate. Fig. 15. Internal view showing six cingular plates $(\mathrm{C} 1-\mathrm{C} 6)$. Fig. 16. Ventral view showing $\mathrm{Sa}, \mathrm{Ss}, \mathrm{Sd}$, Sp plates, and L.s.l. (arrow), i.s.l. (arrowhead). Scale bars $=10 \mu \mathrm{m}$.

Figs 17-20. Light micrographs of live cells of Bysmatrum subsalsum from Malaysian strains TBBYS02 (17-19) and TBBYS03 (20). Fig. 17. Ventral view showing the gross morphology and cingulum displacement. Fig. 18. Ventral view showing the banded chloroplasts (c) and a red eyespot in the sulcal area (arrow).

Fig. 19. Dorsal view showing an elongated nucleus (n) and numerous 
chloroplasts (c). Fig. 20. Dorsal view showing an elongated nucleus (n) (Sybr

Green staining). Scale bars $=10 \mu \mathrm{m}$.

Figs 21-24. Transmission electron micrographs of vegetative cells of Bysmatrum subsalsum strain TBBYS02. Fig. 21. A longitudinal section through the cell showing a nucleus (n), several chloroplasts (c) and an eyespot (arrow). Fig. 22. Several chloroplasts (c) with terminal pyrenoids (p). Fig. 23. An eyespot (e) comprising two rows of lipid globules located within a chloroplast (c) nearby the sulcus. Fig. 24. Detail of the eyespot showing one row of overlying brick-like crystals (arrows). Scale bars: Fig. $21=10 \mu \mathrm{m}$; Figs $22-24=1 \mu \mathrm{m}$.

Figs 25-30. Scanning electron micrographs of vegetative cells of Bysmatrum gregarium strain TIO316. Fig. 25. Ventral view showing the first apical plate. Fig. 26. Dorsal view showing the cingulum plates. Fig. 27. Apical view showing four apical plates $\left(1^{\prime}-4^{\prime}\right)$, three anterior intercalary (1a, 2a and 3a) plates and seven precingular plates $\left(1^{\prime \prime}-7^{\prime \prime}\right)$. Fig. 28. Antapical view showing five postcingular plates $\left(1^{\prime \prime \prime}-5^{\prime \prime \prime}\right)$, two antapical plates $\left(1^{\prime \prime \prime \prime}, 2^{\prime \prime \prime \prime}\right)$ of unequal size and the left sulcal list (L.s.l.). Fig. 29. Apical pore complex showing the oval pore plate (Po), elongated canal plate (X) and round apical pore. Fig. 30. The sulcus showing an anterior sulcal plate (Sa), a right sulcal plate (Sd), a left sulcal plate $(\mathrm{Ss})$, and a posterior sulcal plate $(\mathrm{Sp})$. Scale bars $=10 \mu \mathrm{m}$. 
879 Figs 31-36. Scanning electron micrographs of vegetative cells of Bysmatrum

880

881

882

883

884

885

886

887

888

889

890

891

892

893

894

895

896

897

898

899

900

granulosum strain SP004. Fig. 31. Ventral view showing the first apical plate (1')

and cingulum displacement. Fig. 32. Left lateral view showing the two anterior

intercalary plates (1a, 2a). Fig. 33. Dorsal view showing the cingulum plates

$(\mathrm{C} 4, \mathrm{C} 5)$ and the third anterior intercalary plate (3a). Fig. 34. Apical view

showing the apical pore complex, four apical plates $\left(1^{\prime}-4^{\prime}\right)$, three anterior

intercalary (1a, 2a and 3a) plates and seven precingular plates $\left(1^{\prime \prime}-7^{\prime \prime}\right)$. Fig. 35.

Antapical view showing five postcingular plates $\left(1^{\prime \prime \prime}-5^{\prime \prime \prime}\right)$, two antapical plates $\left(1^{\prime \prime \prime \prime}, 2^{\prime \prime \prime \prime}\right)$ of unequal size and the left sulcal list (L.s.l.). Fig. 36. The sulcus showing an anterior sulcal plate (Sa), a right sulcal plate ( $\mathrm{Sd})$, a left sulcal plate (Ss), a posterior sulcal plate (Sp), and and the internal sulcal list (i.s.l.). Scale bars $=10 \mu \mathrm{m}$.

Figs 37-39. Plate overlaps of epitheca in Bysmatrum, Vulcanodinium and Parvodinium. Fig. 37. Plate overlaps of Bysmatrum subsalsum. Fig. 38. Plate overlaps of Vulcanodinium rugosum. Fig. 39. Plate overlaps of Parvodinium umbonatum.

Fig. 40. Phylogeny of Bysmatrum inferred from concatenated SSU, partial LSU rDNA and ITS sequences using Bayesian inference. New sequences are indicated in bold. Branch lengths are drawn to scale, with the scale bar indicating the number of nucleotide substitutions per site. The long braches are reduced in size 
with their actual size indicated. Numbers on branches are statistical support

values to clusters on the right of them (left: maximum likelihood bootstrap support values; right: Bayesian posterior probabilities). Black circles indicate maximal support (bootstrap $=100 \%$ in ML and $p p=1.00$ in BI respectively).

Fig. 41. Micro-Fourier transform infrared spectra of three Bysmatrum subsalsum cysts from France.

Figs S1-S6. Scanning electron micrographs of vegetative cells of Bysmatrum subsalsum from Malaysian strain TBBYS03. Fig. S1. Left lateral view showing the elongated 1a plate and three cingular plates $(\mathrm{C} 1-\mathrm{C} 3)$. Fig. S2. Apical view showing four apical plates $\left(1^{\prime}-4^{\prime}\right)$, three anterior intercalary (1a, 2a and 3a) plates and seven precingular plates $\left(1^{\prime \prime}-7^{\prime \prime}\right)$. Fig. S3. Dorsal view showing three anterior intercalary (1a, 2a and 3a) plates. Fig. S4. Ventral view showing five postcingular plates (1"' $\left.5^{\prime \prime \prime}\right)$ and two antapical plates (1"'", $\left.2^{\prime \prime \prime \prime}\right)$ of unequal size. Fig. S5. The sulcus showing the anterior sulcal plate (Sa), left sulcal plate (Ss), right sulcal plate $(\mathrm{Sd})$, posterior sulcal plate (Sp), the left sulcal list (L.s.l.) and the internal sulcal list (i.s.1.). Fig. S6. Antapical view showing five postcingular plates $\left(1^{\prime \prime \prime}-5^{\prime \prime \prime}\right)$ and two antapical plates $\left(1^{\prime \prime \prime \prime}, 2^{\prime \prime \prime \prime}\right)$ of unequal size. Scale bars $=10 \mu \mathrm{m}$.

Figs S7-S12. Scanning electron micrographs of vegetative cells of Bysmatrum granulosum strain A10-P14-R2. Fig. S7. Ventral view showing the first apical plate 
923 and cingulum displacement. Fig. S8. Left lateral view showing the two anterior

924 intercalary plates (1a, 2a). Fig. S9. Dorsal view showing the cingulum plates and the 925 third anterior intercalary plate (3a). Fig. S10. Apical view showing the apical pore 926 complex, four apical plates $\left(1^{\prime}-4^{\prime}\right)$, three anterior intercalary $(1 \mathrm{a}, 2 \mathrm{a}$ and $3 \mathrm{a})$ plates 927 and seven precingular plates $\left(1^{\prime \prime}-7^{\prime \prime}\right)$. Fig. S11. Antapical view showing five 928 postcingular plates $\left(1^{\prime \prime \prime}-5^{\prime \prime \prime}\right)$, two antapical plates $\left(1^{\prime \prime \prime \prime}, 2^{\prime \prime \prime \prime}\right)$ of unequal size and the 929 left sulcal list (L.s.l.). Fig. S12. The sulcus showing an anterior sulcal plate (Sa), a 930 right sulcal plate (Sd), a left sulcal plate (Ss), and a posterior sulcal plate (Sp). Scale $931 \quad$ bars $=10 \mu \mathrm{m}$. 


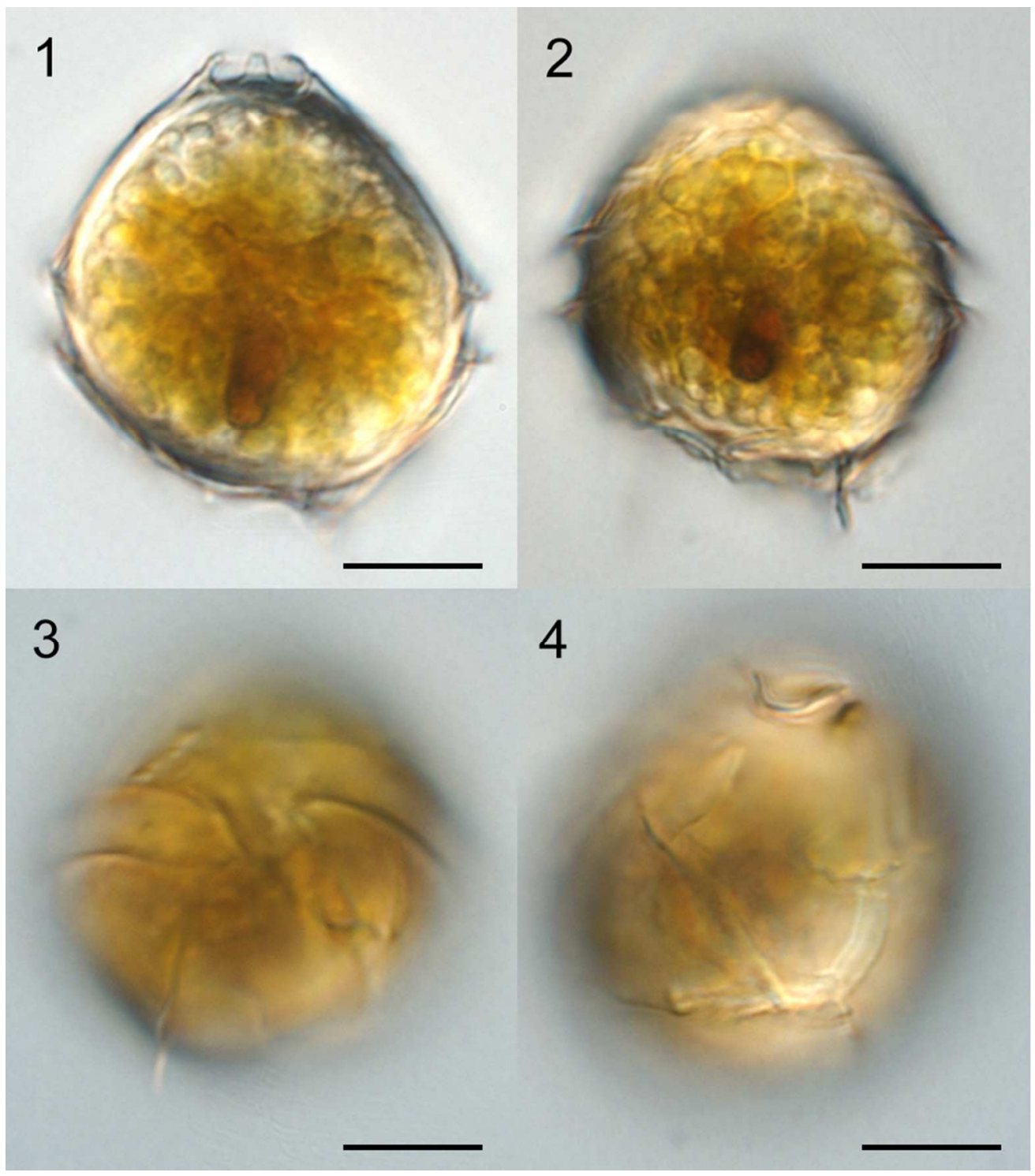

Figs 1-4. Light micrographs of live cysts of Bysmatrum subsalsum from France. Fig. 1. Ventral view in midfocus showing numerous granules, a red accumulation body and the apical stalk. Fig. 2. Dorsal view showing numerous granules, a red accumulation body. Fig. 3. Ventral view showing the cingulum displacement. Fig. 4. Dorsal view showing the plates. Scale bars $=10 \mu \mathrm{m}$.

\section{$80 \times 90 \mathrm{~mm}(300 \times 300$ DPI $)$}




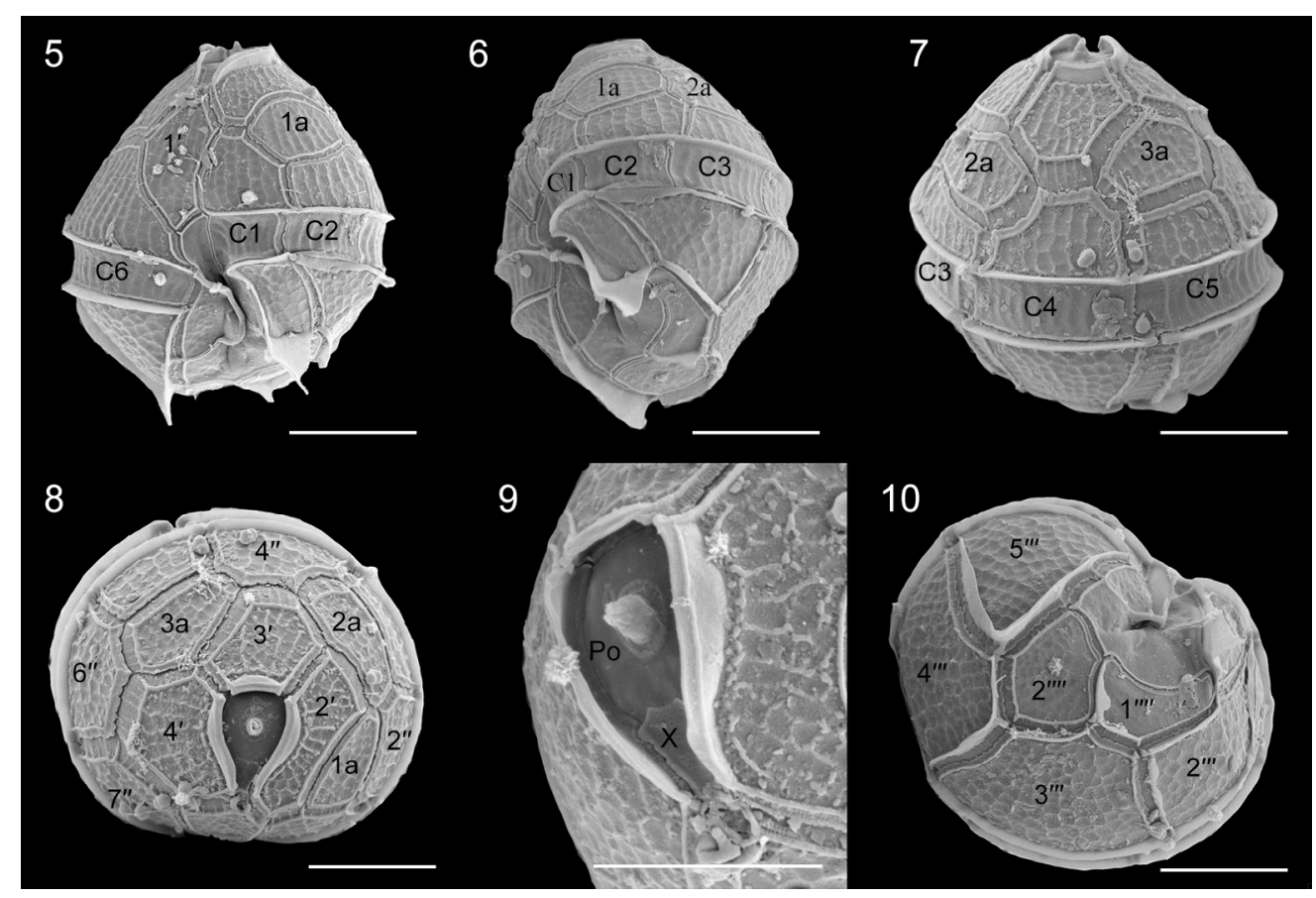

Figs 5-10. Scanning electron micrographs of cysts of French Bysmatrum subsalsum. Fig. 5. Ventral view showing the first apical plate and cingulum displacement. Fig. 6. Left lateral view showing the first three cingular plates (C1, C2 and C3). Fig.7. Dorsal view showing the separation of plates $2 a$ and 3a. Fig. 8. Apical view showing four apical plates $\left(1^{\prime}-4^{\prime}\right)$, three anterior intercalary $(1 a, 2 a$ and $3 a)$ plates and seven precingular plates $\left(1^{\prime \prime}-7^{\prime \prime}\right)$. Fig. 9. Apical pore complex showing the apical stalk emerging from the apical pore, pore plate (Po) and the narrow canal plate $(X)$. Fig. 10. Antapical view showing five postcingular plates $\left(1^{\prime \prime \prime}-5^{\prime \prime \prime}\right)$ and two antapical plates $\left(1^{\prime \prime \prime}, 2^{\prime \prime \prime \prime}\right)$ of unequal size. Scale bars $=10 \mu \mathrm{m}$.

$170 \times 114 \mathrm{~mm}(300 \times 300 \mathrm{DPI})$ 


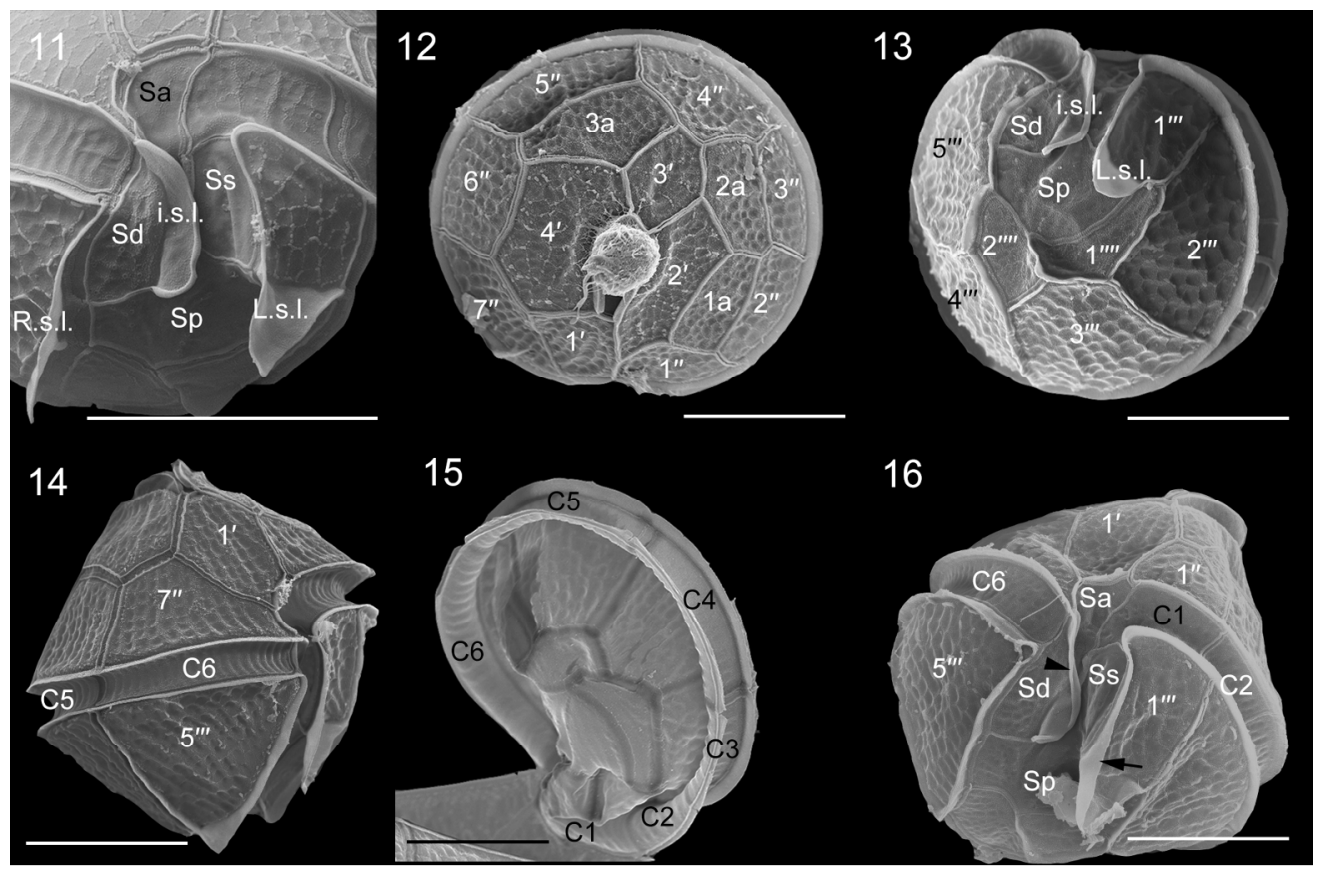

Figs 11-16. Scanning electron micrographs of vegetative cells of Bysmatrum subsalsum from French strain TIO406 (11) and Malaysian strain TBBYS02 (12-16). Fig. 11. The sulcus showing the anterior sulcal plate $(\mathrm{Sa})$, left sulcal plate $(\mathrm{Ss})$, right sulcal plate $(\mathrm{Sd})$, posterior sulcal plate $(\mathrm{Sp})$, the right sulcal list (R.s.l.), the left sulcal list (L.S.I.) and the internal sulcal list (i.s.l.). Fig. 12. Apical view showing four apical plates (1' $\left.4^{\prime}\right)$, three anterior intercalary $(1 a, 2 a$ and $3 a)$ plates and seven precingular plates $\left(1^{\prime \prime}-7^{\prime \prime}\right)$. Fig. 13 . Antapical view showing five postcingular plates $\left(1^{\prime \prime \prime}-5^{\prime \prime \prime}\right)$ and left and internal sulcal lists. Fig. 14. Right lateral view showing the first apical plate. Fig. 15. Internal view showing six cingular plates (C1 - C6). Fig. 16. Ventral view showing Sa, Ss, Sd, Sp plates, and L.s.I. (arrow), i.s.I. (arrowhead). Scale bars $=10 \mu \mathrm{m}$.

$$
170 \times 111 \mathrm{~mm}(300 \times 300 \mathrm{DPI})
$$



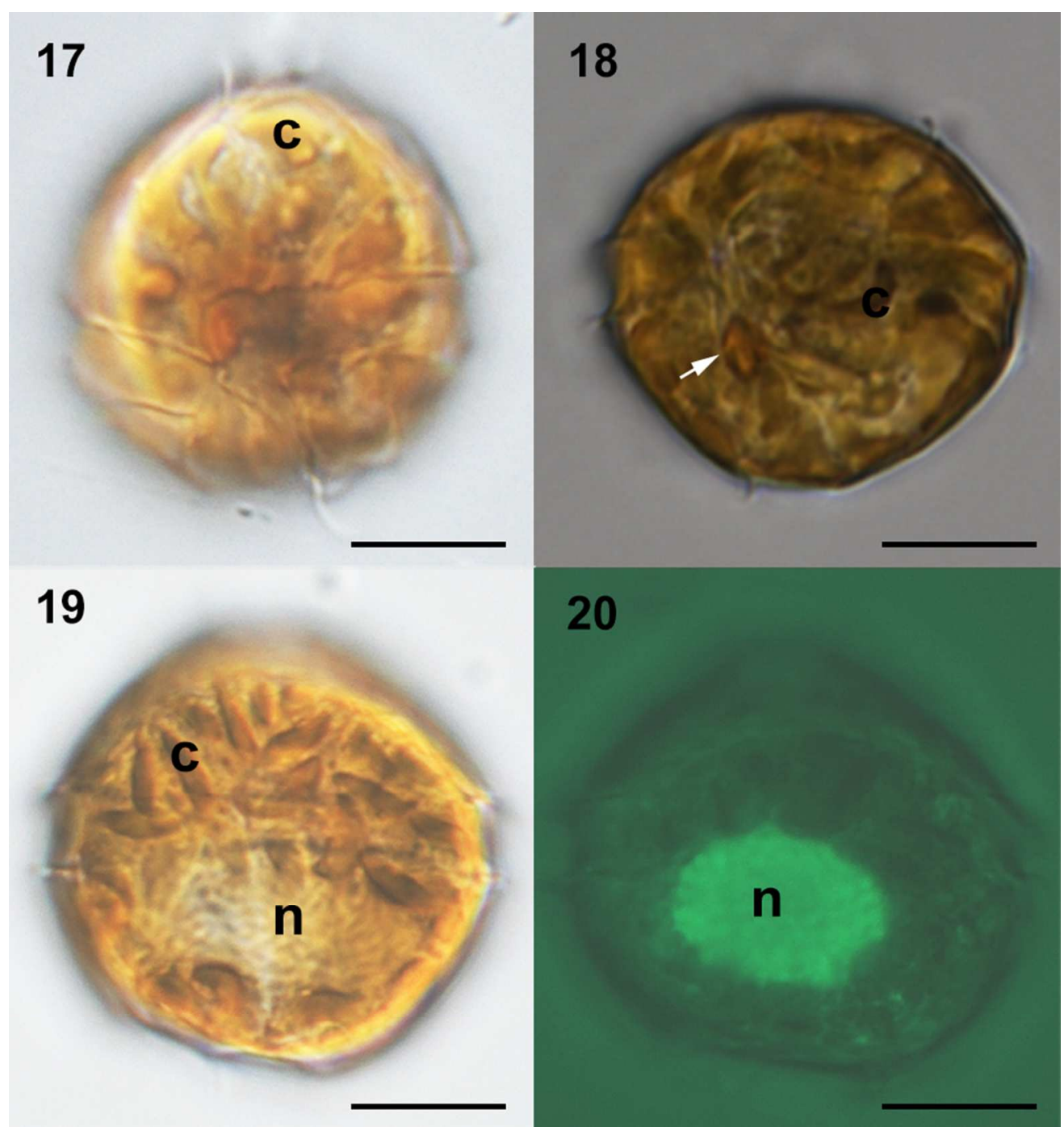

Figs 17-20. Light micrographs of live cells of Bysmatrum subsalsum from Malaysian strains TBBYS02 (1719) and TBBYS03 (20). Fig. 17. Ventral view showing the gross morphology and cingulum displacement. Fig. 18. Ventral view showing the banded chloroplasts (c) and a red eyespot in the sulcal area (arrow). Fig. 19. Dorsal view showing an elongated nucleus ( $n$ ) and numerous chloroplasts (c). Fig. 20. Dorsal view showing an elongated nucleus ( $\mathrm{n}$ ) (Sybr Green staining). Scale bars $=10 \mu \mathrm{m}$.

\section{$80 \times 84 \mathrm{~mm}(300 \times 300 \mathrm{DPI})$}




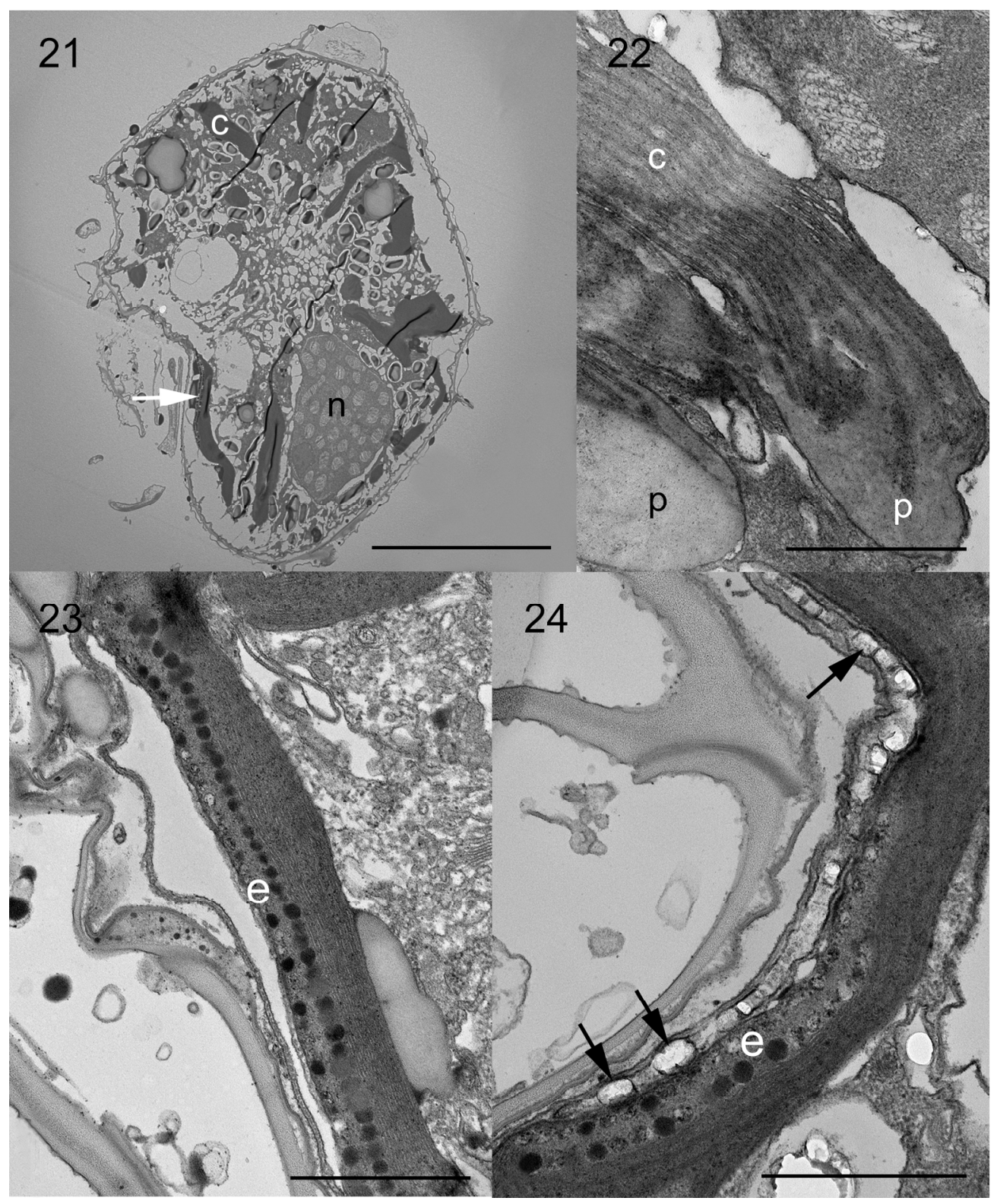

Figs 21-24. Transmission electron micrographs of vegetative cells of Bysmatrum subsalsum strain TBBYS02.

Fig. 21. A longitudinal section through the cell showing a nucleus ( $n)$, several chloroplasts (c) and an eyespot (arrow). Fig. 22. Several chloroplasts (c) with terminal pyrenoids (p). Fig. 23. An eyespot (e) comprising two rows of lipid globules located within a chloroplast (c) nearby the sulcus. Fig. 24 . Detail of the eyespot showing one row of overlying brick-like crystals (arrows). Scale bars: Fig. $21=10 \mu \mathrm{m}$; Figs 22-24 $=1 \mu \mathrm{m}$.

$170 \times 205 \mathrm{~mm}(300 \times 300$ DPI $)$ 


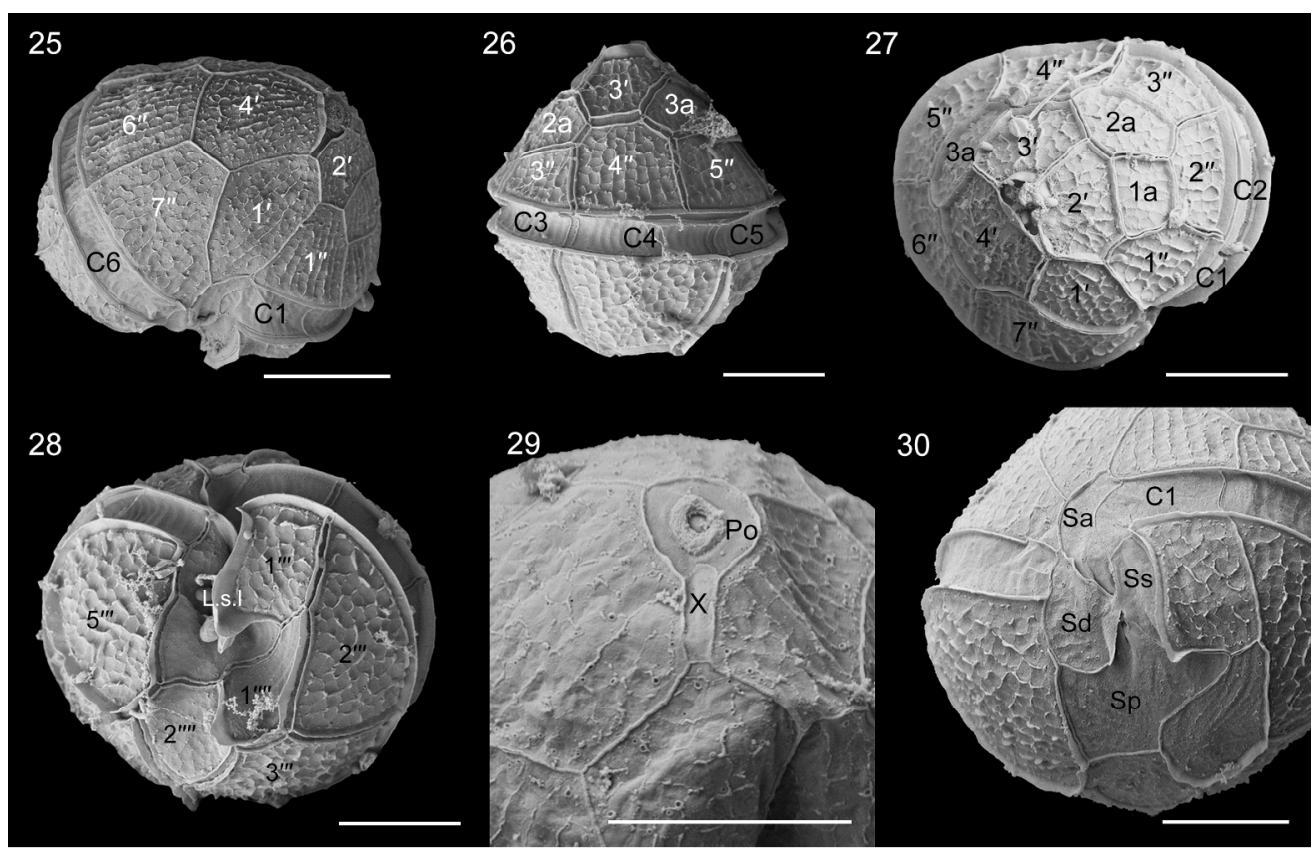

Figs 25-30. Scanning electron micrographs of vegetative cells of Bysmatrum gregarium strain TIO316. Fig. 25. Ventral view showing the first apical plate. Fig. 26. Dorsal view showing the cingulum plates. Fig. 27. Apical view showing four apical plates $\left(1^{\prime}-4^{\prime}\right)$, three anterior intercalary $(1 a, 2 a$ and $3 a)$ plates and seven precingular plates $\left(1^{\prime \prime}-7^{\prime \prime}\right)$. Fig. 28. Antapical view showing five postcingular plates $\left(1^{\prime \prime \prime}-5^{\prime \prime \prime}\right)$, two antapical plates $\left(1^{\prime \prime \prime}, 2^{\prime \prime \prime \prime}\right)$ of unequal size and the left sulcal list (L.s.I.). Fig. 29. Apical pore complex showing the oval pore plate (Po), elongated canal plate (X) and round apical pore. Fig. 30. The sulcus showing an anterior sulcal plate (Sa), a right sulcal plate (Sd), a left sulcal plate (Ss), and a posterior sulcal plate (Sp). Scale bars $=10 \mu \mathrm{m}$.

$209 \times 134 \mathrm{~mm}(300 \times 300$ DPI $)$ 


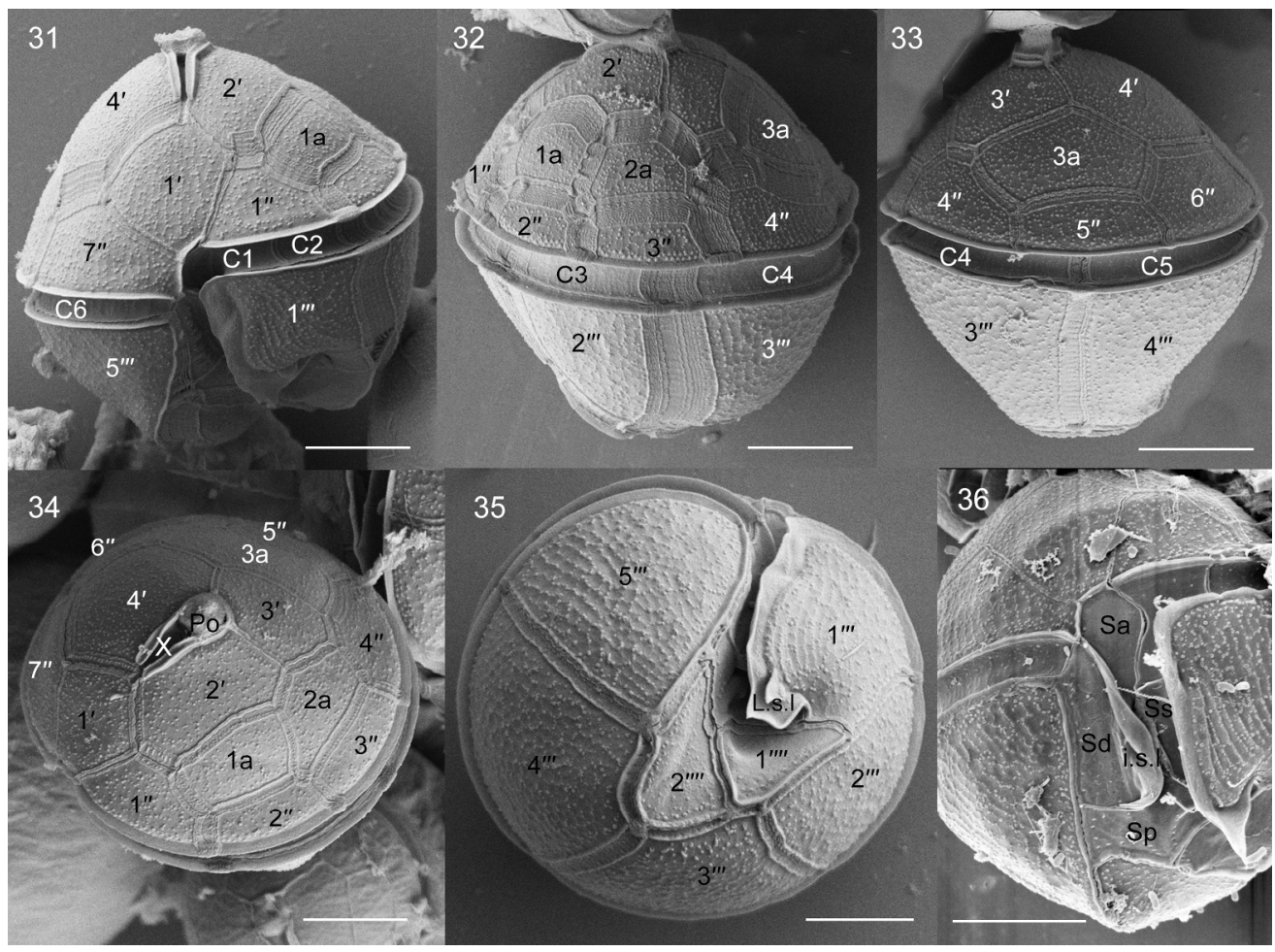

Figs 31-36. Scanning electron micrographs of vegetative cells of Bysmatrum granulosum strain SP004. Fig. 31. Ventral view showing the first apical plate $\left(1^{\prime}\right)$ and cingulum displacement. Fig. 32. Left lateral view showing the two anterior intercalary plates (1a, 2a). Fig. 33. Dorsal view showing the cingulum plates (C4, $\mathrm{C5}$ ) and the third anterior intercalary plate (3a). Fig. 34. Apical view showing the apical pore complex, four apical plates $\left(1^{\prime}-4^{\prime}\right)$, three anterior intercalary $(1 a, 2 a$ and $3 a)$ plates and seven precingular plates ( $1^{\prime \prime}-$ $\left.7^{\prime \prime}\right)$. Fig. 35. Antapical view showing five postcingular plates $\left(1^{\prime \prime \prime}-5^{\prime \prime \prime}\right)$, two antapical plates $\left(1^{\prime \prime \prime \prime}, 2^{\prime \prime \prime \prime}\right)$ of unequal size and the left sulcal list (L.s.l.). Fig. 36. The sulcus showing an anterior sulcal plate (Sa), a right sulcal plate (Sd), a left sulcal plate (Ss), a posterior sulcal plate (Sp), and and the internal sulcal list (i.s.I.). Scale bars $=10 \mu \mathrm{m}$.

$209 \times 155 \mathrm{~mm}(300 \times 300$ DPI $)$ 

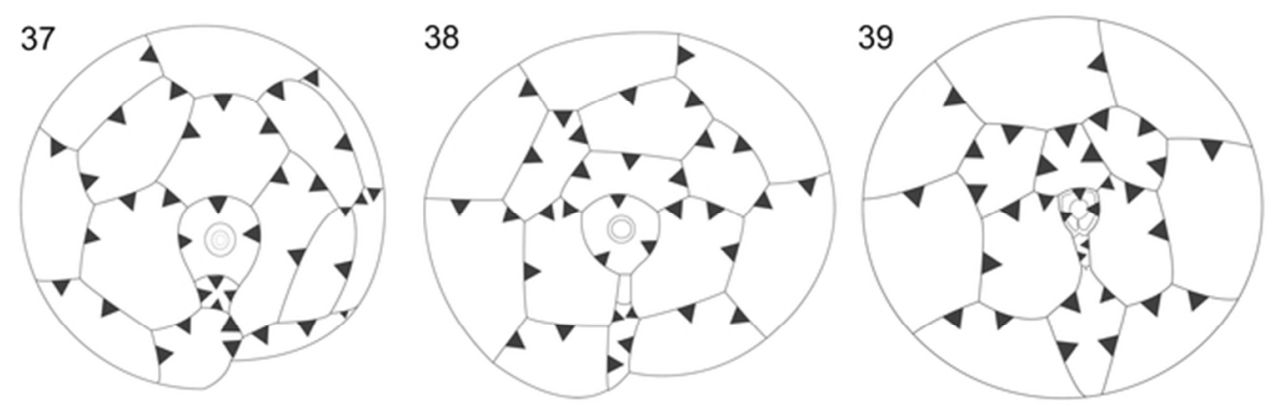

Figs 37-39. Plate overlaps of epitheca in Bysmatrum, Vulcanodinium and Parvodinium. Fig. 37. Plate overlaps of Bysmatrum subsalsum. Fig. 38. Plate overlaps of Vulcanodinium rugosum. Fig. 39. Plate overlaps of Parvodinium umbonatum.

$$
58 \times 19 \mathrm{~mm}(300 \times 300 \text { DPI })
$$




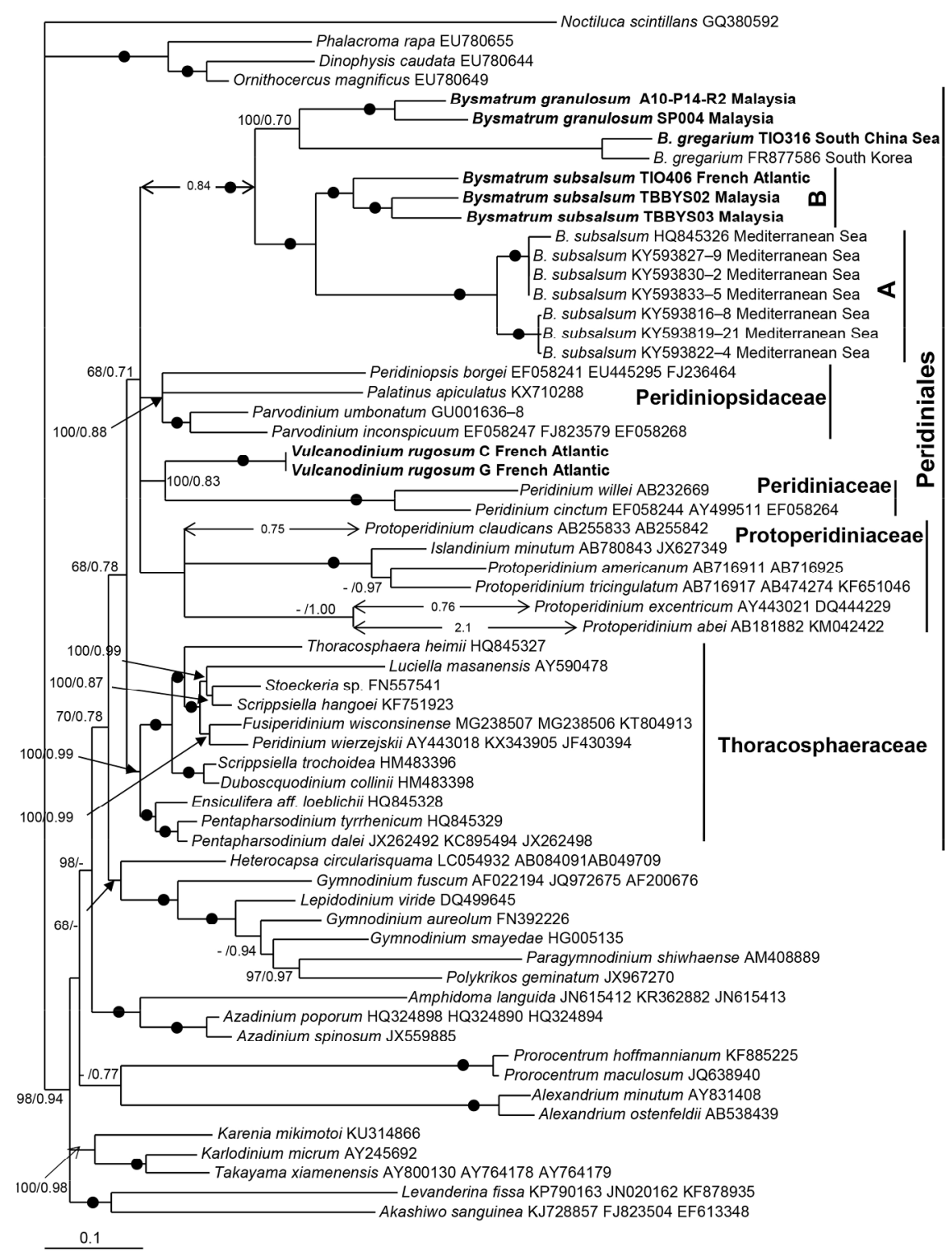

Fig. 40. Phylogeny of Bysmatrum inferred from concatenated SSU, partial LSU rDNA and ITS sequences using Bayesian inference. New sequences are indicated in bold. Branch lengths are drawn to scale, with the scale bar indicating the number of nucleotide substitutions per site. The long braches are reduced in size with their actual size indicated. Numbers on branches are statistical support values to clusters on the right of them (left: maximum likelihood bootstrap support values; right: Bayesian posterior probabilities). Black circles indicate maximal support (bootstrap $=100 \%$ in $\mathrm{ML}$ and $\mathrm{pp}=1.00$ in $\mathrm{BI}$ respectively).

$259 \times 346 \mathrm{~mm}(300 \times 300 \mathrm{DPI})$ 


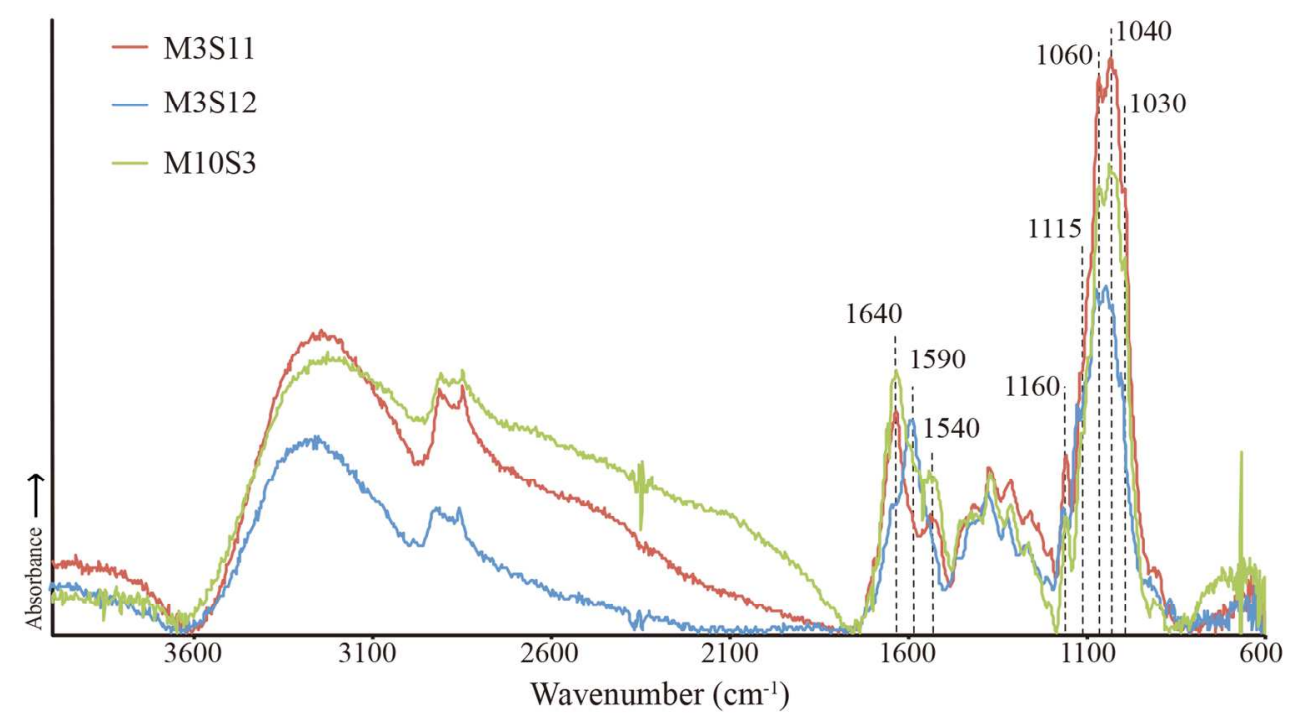

Fig. 41. Micro-Fourier transform infrared spectra of three Bysmatrum subsalsum cysts from France. $170 \times 97 \mathrm{~mm}(300 \times 300 \mathrm{DPI})$ 
Table 1. Bysmatrum strains examined in the present study, including the collection locality, coordinates and collection date.

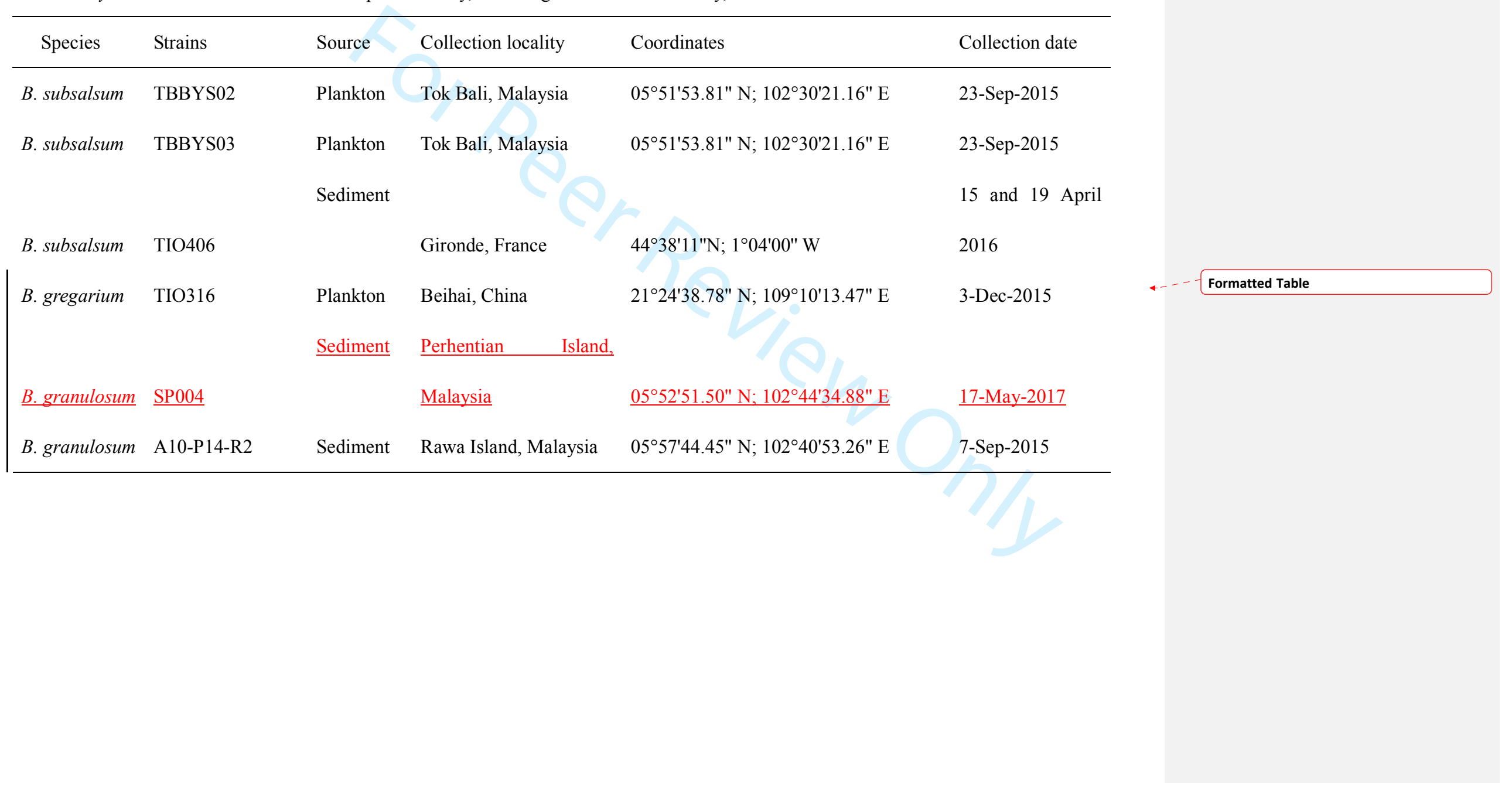


4 6 7

Table 2 Morphological comparisons of Bysmatrum strains examined in the present study with closely related species. SCS: South China Sea; SAPC: Shape of Apical Pore Complex (APC, Po + X plates); L / W of 1a: Length: width ratio of 1a (average); NA: not available.

\begin{tabular}{|c|c|c|c|c|c|c|}
\hline Species & Bysmatrum subsalum & Bysmatrum subsalum & Bysmatrum subsalum & Bysmatrum subsalum & Bysmatrum subsalum & Bysmatrum subsalum \\
\hline Strains/origin & TBBYS02/SCS & TBBYS03/SCS & TIO406/French Atlantic & Aral Sea & Argentina & Florida, USA \\
\hline Shape in ventral view & Pentagonal & Pentagonal & Pentagonal & Pentagonal & Pentagonal & Pentagonal \\
\hline Shape in apical view & Oval, slightly & Oval, slightly & Oval, slightly & Oval, slightly & Oval, slightly & Oval, slightly \\
\hline & dorsoventrally compressed & dorsoventrally compressed & dorsoventrally compressed & dorsoventrally compressed & dorsoventrally compressed & dorsoventrally compressed \\
\hline Apical stalk & Yes & Yes & Yes & NA & NA & NA \\
\hline Nucleus & Elongated, hypothecal & Elongated, hypothecal & NA & NA & Rounded & Elongated, in the center \\
\hline Eyespot & Type B & Yes & NA & NA & NA & Yes \\
\hline Thecal pore & Yes & Yes & Yes & NA & NA & NA \\
\hline Thecal pore size $(\mu \mathrm{m})$ & $0.1-0.2$ & $0.1-0.3$ & $0.14-0.28$ & NA & NA & NA \\
\hline SAPC & Teardrop & Teardrop & Teardrop & NA & NA & NA \\
\hline APC length $(\mu \mathrm{m})$ & $7.5-8.8(8.3, n=7)$ & $6.7-9.1(7.8, \mathrm{n}=16)$ & $7.5-8.8(8.2, n=4)$ & NA & NA & NA \\
\hline APC width $(\mu \mathrm{m})$ & $3.4-4.5(3.9, \mathrm{n}=7)$ & $3.0-4.0(3.4, n=16)$ & $3.2-3.5(3.4, n=4)$ & NA & NA & NA \\
\hline Cell length $(\mu \mathrm{m})$ & $26.0-34.8$ & $26.5-36.5$ & $22.7-31.7$ & $40-46$ & $22.5-32$ & $23.5-41$ \\
\hline Cell width $(\mu \mathrm{m})$ & $24.7-31.4$ & $22.0-29.4$ & $26.0-36.9$ & $38-44$ & $16-29$ & $21-51$ \\
\hline Length: width ratio & $1.0-1.2$ & $0.9-1.2$ & $1.1-1.2$ & NA & NA & NA \\
\hline 1st apical plate & Pentagonal & Pentagonal & Pentagonal & Pentagonal & Pentagonal & Pentagonal \\
\hline 1a morphology & Elongated rectangular & Elongated rectangular & Elongated rectangular & Elongated rectangular & Elongated rectangular & Pentagonal (rectangular) \\
\hline $\mathrm{L} / \mathrm{W}$ of $1 \mathrm{a}$ & $1.8-4.0(2.5, \mathrm{n}=14)$ & $1.8-4.8(3.4, \mathrm{n}=14)$ & $1.2-3.5(1.9, \mathrm{n}=16)$ & 1.8 & 2.7 & NA \\
\hline 2a morphology & Hexagonal & Hexagonal & Hexagonal & Pentagonal & Hexagonal & Pentagonal (hexagonal) \\
\hline 3a morphology & Pentagonal & Pentagonal & Pentagonal & Pentagonal & Pentagonal & Pentagonal \\
\hline $\begin{array}{l}\text { Length of upper: } \\
\text { lower side of } 2 "\end{array}$ & $0.69-0.90(0.83, \mathrm{n}=13)$ & $0.60-0.82(0.74, n=14)$ & $0.63-0.84(0.74, n=14)$ & 0.75 & 0.63 & 0.7 \\
\hline Cingulum width $(\mu \mathrm{m})$ & $3.3-4.3(3.8, \mathrm{n}=20)$ & $2.9-4.2(3.6, \mathrm{n}=20)$ & $3.5-4.2(3.8, \mathrm{n}=20)$ & NA & NA & $3.0-5.0$ \\
\hline $\begin{array}{c}\text { Cingulum } \\
\text { displacement }\end{array}$ & 1 & 1 & 1 & 1 & 1 & 1 \\
\hline Sulcal list & 2 & 2 & 3 & 3 & 3 & 3 \\
\hline Plate ornamentations & Reticulated & Reticulated & Reticulated & Reticulated & Reticulated & Reticulated \\
\hline Cyst production & NA & NA & yes & yes & NA & NA \\
\hline Cyst shape & NA & NA & Ovoid maintaining theca & NA & NA & NA \\
\hline Cyst size $(\mu \mathrm{m})$ & NA & NA & L: $30.0-40.9 ; \mathrm{W}: 26.9-34.3$ & NA & NA & NA \\
\hline
\end{tabular}




\begin{tabular}{|c|c|c|c|c|c|c|}
\hline Reference & Present study & Present study & Present study & Ostenfeld 1908 & Balech 1964 & Stedinger \& Balech 1977 \\
\hline \multicolumn{7}{|c|}{ Table 2 continued } \\
\hline Species & Bysmatrum subsalum & Bysmatrum subsalum & Bysmatrum subsalum & Bysmatrum gregarium & Bysmatrum granulosum & Bysmatrum granulosum \\
\hline \multirow[t]{2}{*}{ Strains/origin } & East China Sea/ & East Mediterranean Sea & West Mediterranean Sea & TIO316/SCS & SP004/SCS & A10-P14-R2/SCS \\
\hline & Caribbean Sea & & & & & \\
\hline Shape in ventral view & Pentagonal & Pentagonal/ovoid & Pentagonal/ovoid & Pentagonal & Pentagonal & Pentagonal \\
\hline \multirow[t]{2}{*}{ Shape in apical view } & & Oval, slightly & Oval, slightly & Oval, slightly dorsoventrally & Oval, dorsoventrally & Oval, dorsoventrally \\
\hline & & dorsoventrally compressed & dorsoventrally compressed & compressed & compressed & compressed \\
\hline Apical stalk & NA & NA & Yes & NA & Yes & NA \\
\hline Nucleus & NA & NA & Hypothecal & NA & Elongated, in the center & NA \\
\hline Eyespot & $\mathrm{NA}$ & NA & Yes & Yes & NA & $\mathrm{NA}$ \\
\hline Thecal pore & NA & $\mathrm{NA}$ & Yes & Yes & Yes & Yes \\
\hline \multirow[t]{2}{*}{ Thecal pore size $(\mu \mathrm{m})$} & $\mathrm{NA}$ & NA & $0.03-0.09$ for smaller pores, & $0.19-0.31$ & $0.14-0.28$ & $0.14-0.28$ \\
\hline & & & $0.10-0.20$ for larger ones & & & \\
\hline SAPC & $\mathrm{NA}$ & Teardrop? & Teardrop/polygonal & Teardrop & Polygonal & Polygonal \\
\hline APC length $(\mu \mathrm{m})$ & 6.5 & $\mathrm{NA}$ & $3.7-10.8(7.2, \mathrm{n}=72)$ & $5.5-6.7(6.2)$ & $5.3-8.9(6.9)$ & $5.1-9.8(7.4)$ \\
\hline APC width $(\mu \mathrm{m})$ & 2.3 & NA & $2.5-7.4(4.7, \mathrm{n}=72)$ & $2.1-3.1(2.8)$ & $1.4-3.5(2.6)$ & $2.1-4.3(2.8)$ \\
\hline Cell length $(\mu \mathrm{m})$ & $32-41$ & $21-45$ & $22.3-50$ & $24.9-37.9$ & $36.4-42.8$ & $37.7-55.4$ \\
\hline Cell width $(\mu \mathrm{m})$ & $28-37$ & $23-47$ & $19.8-50$ & $25.5-35.9$ & $30.2-42.6$ & $34.8-51.5$ \\
\hline Length: width ratio & NA & NA & $0.9-1.3$ & $0.9-1.1$ & $1.0-1.1$ & $1.0-1.1$ \\
\hline 1st apical plate & Pentagonal & Pentagonal & Pentagonal & Pentagonal & Pentagonal & Pentagonal \\
\hline 1a morphology & Elongated rectangular & Elongated rectangular & Elongated rectangular & Trapezoid & Rectangular & Rectangular/penta \\
\hline Length: width ratio of & 1.6 & 2.5 & $1.9-4.8$ & $0.9-4.0(1.9, n=9)$ & $1.1-2.3(1.5, \mathrm{n}=12)$ & $1.8-4.0(2.6, n=9)$ \\
\hline \multicolumn{7}{|l|}{ 1a (average) } \\
\hline 2a morphology & Hexagonal & Hexagonal & Pentagonal & Hexagonal & Hexagonal & Pentagonal/hexagonal \\
\hline 3a morphology & Pentagonal & Pentagonal & Pentagonal & Pentagonal & Pentagonal & Pentagonal \\
\hline Length of upper: & 0.67 & 0.73 & 0.81 & $0.45-0.57(0.50, \mathrm{n}=7)$ & $0.65-0.85(0.74, \mathrm{n}=12)$ & $0.63-0.84(0.72, \mathrm{n}=7)$ \\
\hline \multicolumn{7}{|l|}{ lower side of 2" } \\
\hline Cingulum width $(\mu \mathrm{m})$ & 3 & $\mathrm{NA}$ & $1.9-6.2(4.0)$ & $2.7-3.4(3.0)$ & $2.3-4.4(3.4)$ & $1.5-3.8(2.5)$ \\
\hline Cingulum & 1 & 1 & $1-1.5$ & 1.5 & 1.5 & 1.5 \\
\hline \multicolumn{7}{|l|}{ displacement } \\
\hline Sulcal list & 2 & 2 & 3 & 2 & 2 & 2 \\
\hline Plate ornamentations & Reticulated & Reticulated & Reticulated & Reticulated & Wart-like projections & Wart-like projections \\
\hline Cyst production & NA & Yes & Yes & NA & NA & NA \\
\hline
\end{tabular}




\begin{tabular}{|c|c|c|c|c|c|c|}
\hline Cyst shape & NA & Rounded without theca & $\begin{array}{l}\text { Ovoid maintaining theca } \\
\text { (1st morphotype) and } \\
\text { rounded without theca (2nd } \\
\text { morphotype) }\end{array}$ & NA & NA & NA \\
\hline Cyst size $(\mu \mathrm{m})$ & NA & $41-51$ in diameter & $\begin{array}{l}\text { L: } 38.8-46.0, \mathrm{~W}: 38.7-44.4 \\
\text { for the } 1 \text { st morphotype; } \\
19.7-20.4 \text { in diameter for } \\
\text { the } 2 \text { nd morphotype }\end{array}$ & NA & NA & NA \\
\hline Reference & Faust 1996 & Gottschling et al. 2012 & Anglès et al. 2017 & Present study & Present study & Present study \\
\hline
\end{tabular}


| Table 3. Uncorrected pairwise distances among Bysmatrum species based on ITS sequences (SCS: South China Sea; MED: Mediterranean Sea).

\begin{tabular}{|c|c|c|c|c|c|c|c|c|c|}
\hline & $\begin{array}{c}\text { B.subsalsu } \\
m \\
\text { TBBYS02 }\end{array}$ & $\begin{array}{c}\text { B.subsalsu } \\
m \\
\text { TBBYS03 }\end{array}$ & $\begin{array}{l}\text { B.subsalsu } \\
\text { m TIO406 }\end{array}$ & $\begin{array}{c}\text { B.subsalsum } \\
\underline{\mathrm{D} 323 \mathrm{HQ} 8453} \\
26\end{array}$ & $\begin{array}{c}\text { B.subsalsu } \\
\text { m FB1 }\end{array}$ & $\begin{array}{c}B . \\
\text { granulosum } \\
\text { A10-P14-R } \\
2\end{array}$ & $\frac{\underline{B .}}{\text { granulosu }}$ & $\begin{array}{c}B . \\
\text { gregariu } \\
m \\
\text { TIO316 }\end{array}$ & $\begin{array}{c}\text { B. } \\
\text { gregariu } \\
m \\
\text { (Korea) }\end{array}$ \\
\hline
\end{tabular}

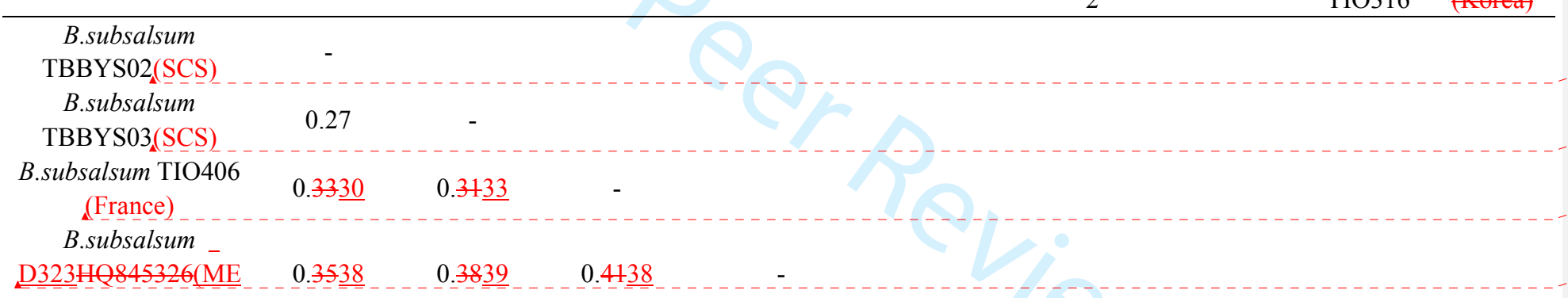
$\underline{\mathrm{D})}$

B.subsalsum

FB1(MED) $\quad 0.34 \underline{35} \quad 0.36 \quad 0.39 \underline{36} \quad 0.09$

- - - -

(1)

0.09

$\begin{array}{cccccc}\begin{array}{l}\text { B. granulosum } \\ \text { A10-P14-R2(SCS) }\end{array} & 0.41 \underline{40} & 0.40 \underline{41} & 0.42 \underline{41} & 0.43 \underline{42} & 0.43 \\ \text { B. granulosum } & \text { Pre }\end{array}$

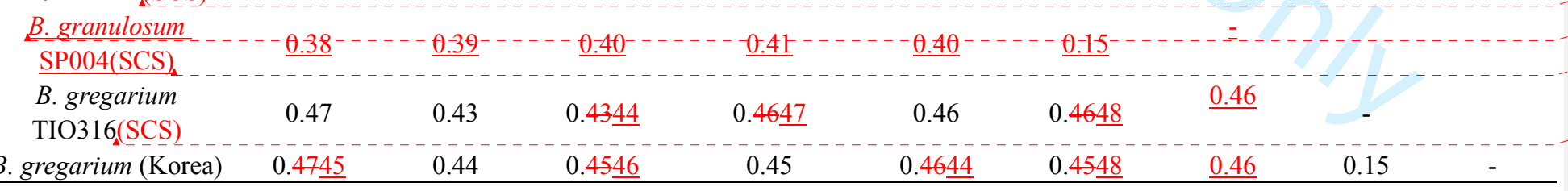

Formatted: Font color: Red

Formatted Table

Formatted: Font color: Red

Formatted: Font color: Red

Formatted: Font color: Red

Formatted: Default Paragraph Font, Font: (Default) Times New Roman, 12 pt

Formatted: Font color: Red

Formatted: Font color: Red

Formatted: Font: Italic

Formatted: Font: Not Italic

Formatted: Font color: Red 


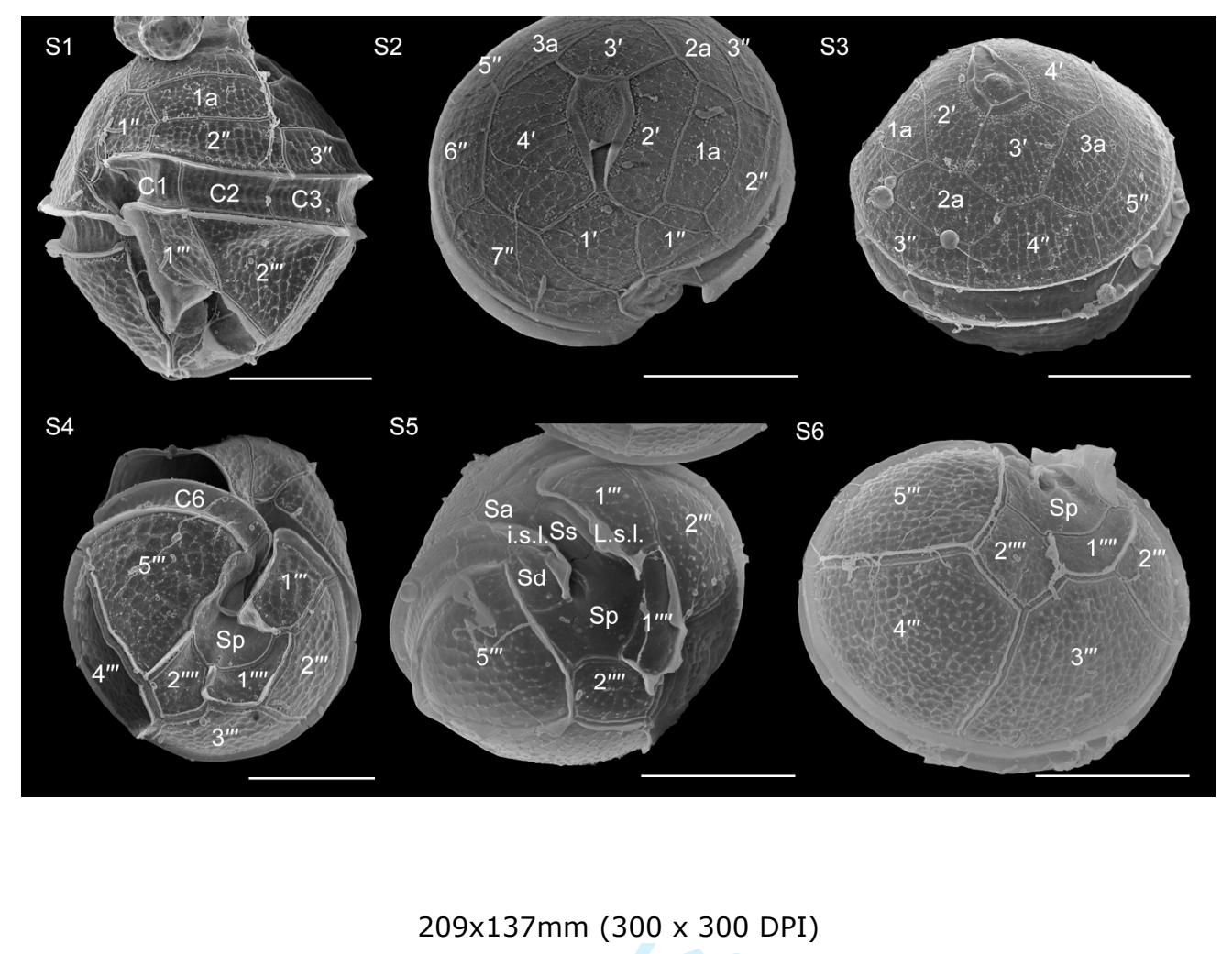




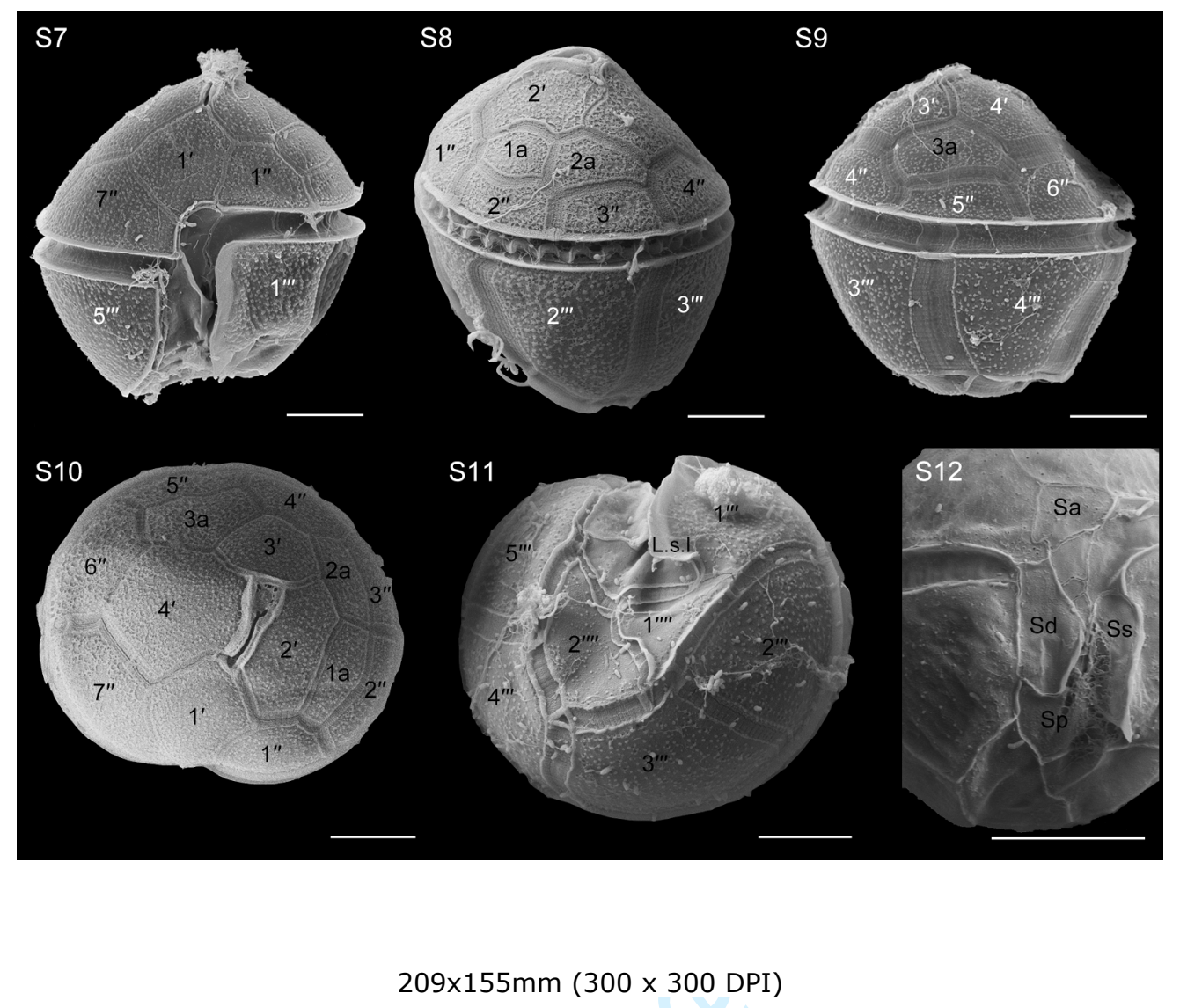


Table S1. GenBank accession numbers of strains or isolates examined in the present study

\begin{tabular}{lllll}
\hline Species & Strains/isolates & SSU & ITS & LSU \\
\hline Bysmatrum subsalsum & TBBYS02 & MG826109 & MG826361 & MG826101 \\
Bysmatrum subsalsum & TBBYS03 & MG826110 & MG826362 & MG826102 \\
Bysmatrum subsalsum & TIO406 & MG826111 & MG826363 & MG826103 \\
Bysmatrum gregarium & TIO316 & MG826112 & MG826364 & MG826104 \\
Bysmatrum granulosum & A10-P14-R2 & MG826108 & MG826360 & MG826100 \\
Bysmatrum granulosum & SP004 & MG826113 & MG826365 & MG826105 \\
Vulcanodinium rugosum & C & MG826114 & MG826366 & MG826106 \\
Vulcanodinium rugosum & G & MG826115 & MG826367 & MG826107 \\
\hline
\end{tabular}

